\title{
The Creative Employee and the Copyright Act of 1976
}

\author{
Rochelle Cooper Dreyfuss $\dagger$
}

Debates on issues in copyright law have long exhibited a clash between alternative visions of the goal that copyright seeks to achieve. One group sees copyright as a means for enhancing the creative environment and so tends to suggest resolutions of open issues that are highly attuned to the interests of authors. ${ }^{1}$ Another camp takes an economic approach centered on questions of public welfare. Under this view, public access emerges as a central concern, and the rights of authors are thought protectable only insofar as they are necessary to stimulate the optimal level of innovative production. ${ }^{2}$ Ralph Brown has recently suggested that neither approach fully captures the social interests that are at stake, and that greater insights might be obtained if the two views were somehow melded. ${ }^{3}$ This paper is an attempt to carry out Professor Brown's proposal.

In merging the author-based and economic approaches, I con-

$†$ Associate Professor of Law, New York University School of Law. B.A., Wellesley College, 1968; M.S., University of California at Berkeley, 1970; J.D., Columbia University, 1981.

I note with sadness the passing of my friend and colleague, Kate McKay. As copyright librarian, Kate was enormously helpful to everyone involved with intellectual property at New York University. The unaffected competence with which she carried out her many public and private roles inspired us all. I also wish to thank Harry First, Jane Ginsburg, Robert Gorman, and Diane Zimmerman for their thoughtful comments, and New York University law students Howard August and Michele Cotton for their research assistance. The Filomen D'Agostino and Max E. Greenberg Research Fund of the New York University School of Law supported research for this article.

1 See, e.g., David Ladd, To Cope with the World Upheaval in Copyright, 19 Copyright 289 (1983); Ralph S. Brown, Eligibility for Copyright Protection: A Search for Principled Standards, 70 Minn. L. Rev. 579, 589 (1985) ("the author should be able to decide when and how to publish his or her personal creation, both as a matter of respect and as a matter of allowing the author to win material rewards as best she can").

2 See, e.g., Stephen G. Breyer, The Uneasy Case for Copyright: A Study of Copyright in Books, Photocopies, and Computer Programs, 84 Harv. L. Rev. 281 (1970); Robert Hurt and Robert Schuchman, The Economic Rationale of Copyright, 56 Amer. Econ. Rev. 421 (1966). Professor Brown states that the economic approach "admires authorship and creativity-but as public goods which should not be constrained by ownership, except where a right to seek a reward is a necessary stimulus to authorship." Brown, $70 \mathrm{Minn}$. L. Rev, at 607 (cited in note 1).

${ }^{3}$ See Brown, 70 Minn. L. Rev. at 589-600. 
tend that attention to nonpecuniary, author-based interests is necessary in order to take full advantage of the talents of the creative and to, in the words of the Constitution, "promote the Progress of Science and useful Arts." To the extent that my focus on authorbased interests emerges from a desire to promote the public interest, I side with the proponents of the economic approach. Yet my conception of the public interest is, I think, broader than theirs. Adherents to the economic approach seem to believe that social utility is measured solely by the public availability of raw output. It is my view that creative production is not equivalent to other kinds of production, and that the public interest in creative enterprises depends upon the quality of the works themselves. In this paper I will argue that this interest is not adequately served by exclusive focus on the pecuniary benefits that copyright analysis traditionally affords.

While there are many (perhaps more important) areas where a fused approach to copyright would be helpful, the treatment of university professors and other creative employees under the "work for hire" doctrine of the 1976 Copyright Act is a promising place to begin. Recent events have made examination of this question timely. The copyright statute enacted in 1976 has modified prior law. Under the Copyright Act of 1909, courts and commentators regarded the work for hire doctrine, which deems an employer the owner of work prepared within the scope of employment, as largely inapplicable to teachers. ${ }^{5}$ Commentators have, however, argued that Congress eliminated this exception to the work for hire doctrine when it passed the Copyright Act of 1976. According to these commentators, the 1976 Act permits universities to claim copyright to, and even "authorship" of, their faculty's output.

At the same time, universities have begun to take a more active interest in the financial dimensions of the faculty's work prod-

4 U.S. Const. art. I, § 8, cl. 8.

- See Copyright Act of 1909, 35 Stat. 1075; Melville B. Nimmer, 1 Nimmer on Copyright § 5.03[B] (1984). Although there are no American cases directly on point, Nimmer based his conclusion on dicta in a number of cases. In Williams v. Weisser, 273 Cal.App.2d 726, 78 Cal.Rptr. 542 (1969), for example, a California court of appeals enjoined a student from publishing his lecture notes. As a necessary predicate to this holding, the court found that the student's professor, and not the university the student attended, owned the common law copyright to the professor's lectures. See also, Comment, Copyright-Works for Hire, 45 N.Y.U. L. Rev. 595, 598-608 (1970).

- See 17 U.S.C. $\S \S 101,201(b)$ (1982); Leonard D. DuBoff, An Academic's Copyright: Publish and Perish, 32 J. Copyright Soc. 17 (1984); Todd F. Simon, Faculty Writings: Are They "Works Made for Hire" Under the 1976 Copyright Act?, 9 J. Coll. \& Univ. L. 485 (1982-83). 
uct, ${ }^{7}$ and increasingly they have come to view exploitation of scholarly output as a means of filling the revenue gaps left by shrinking government grants and student tuition payments. ${ }^{8}$ This trend is not entirely novel, since universities traditionally have required faculty members in the sciences to assign to their employers the patent rights to their inventions. ${ }^{9}$ Yet these new claims for copyright ownership could substantially alter the creative environment for a large segment of the university community. ${ }^{10}$

My argument runs as follows. The academic community is presumptively dedicated mainly to the pursuit of knowledge. ${ }^{11}$ If

7 For recent efforts of universities to exploit the fruits of faculty work product, see The Big Bucks of Biology, Newsweek 69 (Apr. 5, 1982) (describing industrial parks opened near universities to house joint ventures); David Blumenthal, Michael Gluck, Karen Seashore Louis, and David Wise, Industrial Support of University Research in Biotechnology, 231 Sci. 242 (1986) (nearly one-half of all biotechnology companies fund research in universities, accounting for one-quarter of the support for biotechnology in universities). Faculty entrepreneurs have also recently founded companies to exploit the findings of their academic research and have remitted a portion of their earnings to their universities. See Wil Lepkowski, Research Universities Face New Fiscal Realities, Chem. \& Engin. News 23, 31 (Nov. 23, 1981) (describing Carl Djerassi of Stanford University, who founded Synex Corp.); The Tempest Raging Over Profit-Minded Professors, Bus. Week 80 (Nov. 7, 1983) (detailing conflict of interest problem facing faculty entrepreneurs). See also David Dickson, Britain's Ivory Tower Goes High Tech, 227 Sci. 1560 (1985) (describing similar phenomena in Britain).

- For data on the financial problems of American universities, see Michael S. McPherson, Higher Education: Investment or Expense?, in John C. Hoy and Melvin H. Bernstein, eds., Financing Higher Education 15 (1982); Patricia Flynn Pannell, Finance and the Future of Higher Education in New England, in Hoy and Bernstein, eds., Financing Higher Education at 45; The Washington Post, A10, col. 2-3 (Nov. 25, 1985) (citing a drop in full-time students from 7.3 million in 1983 to 6.8 million in 1985 and a drop in federal aid to higher education of $\$ 500$ million between 1980 and 1985).

- See, e.g., Princeton University, Rules and Procedures of the Faculty 100-01 (1982); New York University, Faculty Handbook 118 (1982); JoAnn Moody, Tax Policy: Some Issues for Higher Education, in Hoy and Bernstein, eds., Financing Higher Education 125, 133-34 (cited in note 8). For example, the University of Wisconsin owns and exploits the patent rights to the rat poison Warfarin and to the process for adding vitamin $D$ to milk; Gatorade was developed and trademarked by the University of Florida. See David Zizzo, Patent and Trademark Royalties, U.P.I. (Financial) (Nov. 5, 1982) (available July 25, 1986 on LEXIS, NEXIS library Wires file).

10 The assertion of interest in copyright is not entirely new, for the University of Chicago apparently had such a policy at one time. See Simon, 9 J. Coll. \& Univ. L. at 496 n.68 (cited in note 6). But the Society of University Patent Administrators has only recently begun to consider questions concerning copyrightable materials, and the copyright policies that are in force tend to allow the faculty to retain a greater interest in their copyrighted works than in their patented material. See Frederic H. Erbisch, Survey of Institutional Patent and Copyright Policies and Their Administration 1, 28-29 and summary (1985).

11 See, e.g., Bok's Outline of Right Role for Academy, New York Times § 1, at 31, col. I (Sept. 7, 1986) (excerpts from Harvard University President Derek Bok's statements to a convocation in Harvard Yard); Copyright Law Revision, Hearings Before the Subcomm. on Patents, Trademarks, and Copyrights of the Sen. Comm. on the Judiciary, 89th Cong., 1st Sess. 176 (1965) ("1965 Hearings") (statement of Mark Carroll, Ass'n of Amer. Univ. 
copyright law's sole consequence is the protection of the creator's ability to realize a profit from her creation, then the shift in the work for hire doctrine should have little effect on the quantity, quality, or mix of scholarly output. Thus, if changes in scholarly output do occur when universities claim copyright, it must be that copyright ownership protects interests beyond those that are purely financial-interests in the quality and integrity of the scholarly works. The question then becomes whether lawmakers should more explicitly protect those values. If these nonpecuniary interests are important only to scholars, then arguably scholars and universities should simply sort out their problems contractually. But if protection of these interests also benefits the public, then it is important to analyze and structure copyright law in ways that take these nonpecuniary values into account.

In part I, I summarize commentators' findings regarding the operation of the work for hire doctrine, conclusions that I accept for argument's sake but do not personally endorse. In part II, I demonstrate that the composition of output will change if faculty members lose the copyright to their work, and conclude that vesting the creative with copyright ownership produces nonpecuniary benefits both to the creative and to the public. An economic approach focusing only on creators' monetary rewards would strip the creative of their ability to act as a surrogate for the public, and, in the end, hamper public access to their creativity. In part III, I support this conclusion by demonstrating the extent to which the interests of the creative are, in fact, protected by the law of tort, trademark, and contract. Finally, in part IV, I sketch a view of how the law should operate with regard to the creative employee.

The context in which I have chosen to examine the interplay of the economic and author-based approaches is, unfortunately, not the most hospitable to my argument. Because the interest in faculty work product is recent, there is little empirical data with which to work. I have, accordingly, relied on the writings of other

Presses) (describing role of university presses in "provid[ing] a means of communication between scholars and serv[ing] the advancement of knowledge in the arts and sciences and the professions").

Many academics are, of course, also motivated by a desire to supplement their salaries with royalties from their writings. By diverting these payments to the university, the work for hire doctrine could directly affect faculty compensation. I have, however, chosen to ignore this dimension of the problem and, instead, have chosen to concentrate on the effect of copyright ownership on faculty decisions regarding those works that are not written primarily for financial gain, but rather to advance the frontiers of knowledge. See DuBoff, $32 \mathrm{~J}$. Copyright Soc. at 17 (cited in note 6), for a discussion of the salary question. 
highly creative individuals, on the assumption that people who are intellectually committed share many similar concerns. ${ }^{12}$ In addition, the university's own commitment to scholarship is different from the interests of other employers. Nonetheless, the discussion highlights the need to rethink the structure of federal protection of creative endeavors. ${ }^{13}$

\section{WORK FOR HIRE}

\section{A. The Copyright Act of 1909}

Copyright law has long contained mechanisms to assign the incidents of authorship to a party other than the natural creator. That this should be so is not surprising: it is, in fact, a logical corollary of the hypothesis that production of intellectual property will increase if the law converts creative output from a public good (in the sense that anyone can use an intellectual creation without interfering with anyone else's right of enjoyment) into a private one. ${ }^{14}$ That is, if it is agreed that the right to exclude free riders

12 I believe this is a good assumption for several reasons. First, the concerns articulated by creators who rely exclusively on sales of their work resonate well with concerns expressed by my colleagues. Second, my main focus is on the effects of copyright law on academic work at the forefront of its field: it is here that the university makes its greatest contribution, and it is this work that is most often thought to be unaffected by alteration in the financial rules. This work is probably closest to the kinds of projects discussed in the writings I examine here. Finally, the argument that those "inside the walls" differ from those who remain outside rests on the notion that those who subsidize their intellectual work with outside employment have different attitudes from those who can rely exclusively on their creative efforts. Yet it is likely that even outsiders feel free to innovate only after their basic financial needs have been met. Instead of relying on salaries, they rely on their lucrative projects to subsidize their other work. See, e.g., Lawrence Grobel, Conversations with Capote 88 (1985) (describing Truman Capote's habit of writing magazine articles and screen plays while at the same time working on more ambitious projects); Robert Van Gelder, Writers and Writing 43 (1946) (Katherine Anne Porter wrote "on order" so that she could finance her more inventive activity). See generally U.S. Congress, Office of Technology Assessment, Intellectual Property Rights in an Age of Electronics and Information 128 (April 1986) ("OTA Report") (defining "creators" as "[s]cholars, poets, writers, artists, inventors, and others who produce intellectual works").

1s This issue will shortly come before Congress in several contexts. First, a bill that would alter the work for hire rules with respect to freelance employees was presented to the previous Congress and raised issues very close to the ones considered here. See S.2330, 99th Cong., 2d Sess. (1986). See also S.2796, 99th Cong., 2d Sess. (1986) and H.R. Rep. No. 995722, 99th Cong., 2d Sess. (1986) (giving artists "moral rights" to works of fine art). In addition, if the United States joins the Berne Convention, it may be required to offer more generous protection to the creative than is required under the Universal Copyright Convention to which it now subscribes. See, e.g., S.2904, 99th Cong., 2d Sess. (1986), which calls for the United States to join the Berne Convention.

14 This hypothesis is one that cannot be proven empirically, and some commentators have disagreed with it. See, e.g., Arnold Plant, The Economic Aspects of Copyright in 
will in fact encourage creativity, then the benefits should be made to accrue to the party who put the creative process into motion. And if intellectual products are considered private goods, then one should be able to purchase these goods before they are created, much as one can contract to buy a custom-made home.

In many circumstances, employers neatly fit this characterization, and, accordingly, the common law treated employers as the authors of works created within the scope of employment. ${ }^{15}$ The 1909 Copyright Act codified this approach and deemed the employer the "author" of "works made for hire."16 The Act, however, did not define the term "works made for hire." To fill this omission, courts looked to the policies underlying copyright and the notion of "deemed authorship." Starting with the presumption that works prepared in the course of employment were works for hire,$^{17}$ courts allowed employees to introduce evidence on a variety of factors to rebut the presumption that their work belonged to the employer. This "factors test" also was used when an independent contractor created a work pursuant to a specific, short-term contract. ${ }^{18}$

Under the factors test, courts scrutinized inspiration, ${ }^{19}$ insistence, ${ }^{20}$ and right of supervision and control $^{21}$ to determine

Books, I Economica 167 (new series 1934). In this article, I assume that legal rules can alter creative behavior.

${ }^{16}$ See, e.g., Bleistein v. Donaldson Lithographing Co., 188 U.S. 239, 248 (1903) (implicitly agreeing that employer rather than employee held copyright to advertisements); Colliery Engineer Co. v. United Correspondence Schools Co., 94 F. 152 (C.C.S.D.N.Y. 1899).

16 See, e.g., Copyright Act of 1909, 35 Stat. 1075, 1087-88, current version at 17 U.S.C. $\S \S 101-810$ (1982). Even before the 1909 codification, a bill had been proposed to vest an employer with copyright ownership over his employee's product produced "during the hours for which [the employee's] salary is paid, subject to any agreement to the contrary." At least one commentator has argued that Congress did not include a similar provision in the 1909 Act because it intended the "work for hire" category to include more than just products of salaried employment. Borge Varmer, Study No. 13: Works Made for Hire and on Commission, Copyright Law Revision: Studies Prepared for the Subcomm. on Patents, Trademarks, and Copyrights of the Sen. Comm. on the Judiciary, pursuant to S. Res. 240, 86th Cong., 2d Sess. 123, 128 (April 1958) ("1958 Study").

${ }_{17}$ See, e.g., Murray v. Gelderman, 566 F.2d 1307, 1309-10 (5th Cir. 1978); Yardley v. Houghton Mifflin Co., Inc., 108 F.2d 28, 31 (2d Cir. 1939). See also Donaldson Publishing Co. v. Bregman, Vocco \& Conn, Inc., 375 F.2d 639 (2d Cir. 1967) (allowing employee's survivors to rebut presumption with evidence that parties intended to leave copyright interest with employee).

1s Note, The Freelancer's Trap: Work for Hire Under the Copyright Act of 1976, 86 W. Va. L. Rev. 1305, 1311-16 (1984).

19 See, e.g., Murray, 566 F.2d at 1310 (party that conceived of the notion of a menu book deemed the author); Epoch Producing Corp. v. Killiam Shows, Inc., 522 F.2d 737, 74345 (2d Cir. 1975) (because the film "Birth of a Nation" was the product of D. W. Griffith's inspiration, court deemed Griffith author of the work for copyright purposes even though a production company had financed the project).

${ }^{20}$ See, e.g., Scherr v. Universal Match Corp., 417 F.2d 497, 499 (2d Cir. 1969) (supervi- 
whether it was the employee or the employer who had been motivated to create the work. ${ }^{22}$ For example, one court held that the right to renew the copyright in the song "Who's Afraid of the Big Bad Wolf?" belonged solely to the party who had originally conceived the song, exercised the right to revise it, and paid for its adaptation, rather than to the party who was hired to add new lyrics and ready the work for inclusion in the movie The Three Little Pigs. The court concluded that since the former party was the creative entity, it should enjoy the benefits available under the copyright law. ${ }^{23}$

The bearing of expenses, ${ }^{24}$ the place of creation, ${ }^{25}$ and the nature of compensation ${ }^{26}$ served as further indicia of work made for hire, on the theory that the payment of costs revealed the nature of the underlying contract. Accordingly, one court held that a sculpture conceived of by two soldiers was authored by the United States because the soldiers completed the work at the Army's expense, at Fort Dix, and during the sculptors' regular duty hours as military illustrators. The majority reasoned that a party who allows another to bear the burdens and risks associated with creation has evidenced his understanding that he created the good for the exclusive benefit of the other. ${ }^{27}$

sor's suggestions that work be enlarged used as evidence that work was made for hire); Brattleboro Publishing Co. v. Winmill Publishing Corp., 369 F.2d 565 (2d Cir. 1966) (advertisements designed at the insistence of the advertiser belong to advertisers, not newspaper).

${ }^{31}$ See, e.g., Picture Music, Inc. v. Bourne, Inc., 457 F.2d 1213, 1216 (2d Cir. 1972) (employer made revisions in work); Scherr, 417 F.2d at 501 (employer retained right to control and supervise work); Bregman, Vocco \& Conn, Inc., 375 F.2d at 643 (despite employment contract, work not for hire because employer did not retain the right to supervise).

${ }^{22}$ See Clarkstown v. Reeder, 566 F.Supp. 137, 141-42 (S.D.N.Y. 1983) ("[The] argument [that the party who put pen to paper is the author] improperly places primary emphasis on the efforts of the scribe and not on the genesis of the ideas memorialized in the work.").

${ }^{23}$ Picture Music, 457 F.2d at 1217 (the motivating factor in producing the work was the employer who induced the creation).

${ }^{24}$ See, e.g., Scherr, 417 F.2d at 499; Brattleboro, 369 F.2d at 568.

${ }^{25}$ See, e.g., Bleistein, 188 U.S. at 248; Scherr, 417 F.2d at 499.

${ }^{28}$ See, e.g., Everts v. Arkham House Publishers, Inc., 579 F.Supp. 145, 148 (W.D. Wis. 1984) ("[c]ourts have found that the copyright belong[s] to the purchaser/employer and not the artist/independent contractor when the artist was paid a sum certain for the creation of a work according to the purchaser's specifications"); Bregman, Vocco \& Conn, Inc., 375 F.2d at 642; Tobani v. Carl Fischer, Inc., 98 F.2d 57, 60 (2d Cir. 1938) ("Tobani received his compensation [\$25 per week for life] for preparing the work and it was of little importance to him whether or not it was published.").

${ }^{27}$ Judge Friendly echoed the same theme in dissent. See Scherr, 417 F.2d at 502 ("To allow the artist to retain the copyright would thus deprive the purchaser of his bargain."). For another case looking at the nature of the artist's expectation, see Roth v. Pritikin, 710 F.2d 934, 940 (2d Cir. 1983) ("We are of the view, therefore, that Roth knowingly and pur- 
In addition, in many of the work for hire cases, the courts may have thought that the work would not be adequately disseminated if the copyright ownership was not placed with the employer. ${ }^{28}$ For example, courts usually held that contributions to a motion picture were for hire, so that a single entity would control all the rights. In that way, business decisions related to exploitation of the film could be made more easily than if every decision had to be approved by every contributor to the film. Although this rationale is unstated in many of the cases, it emerges in the materials Congress considered in adopting the 1976 Act. $^{29}$

In light of the factors test, it is not difficult to understand why courts fashioned a "teacher exception" to the work for hire rules." Although universities paid faculty salaries, required (and supported) research, exercised some rudiments of control over the sorts of scholarship that counted toward advancement, and made library and other facilities available for scholarly pursuits, these activities did not usually prove that the university was the motivating force behind the work. ${ }^{31}$ Moreover, because of the long tradition of professorial authorship, courts could not argue that as an implicit term of the employment contract, a faculty member surrendered to the university the copyright in his work..$^{32}$ Indeed, given the principle of academic freedom, which prevents universities from controlling the expression of ideas in scholarly writings, it would have been anomalous for a university to suggest that it exercised enough supervision over its faculty to bring a faculty member's articles and books within the scope of the work for hire doctrine. ${ }^{33}$ Sensitive also to the limiting effect copyright protection has on public access to copyrighted materials, courts were unwilling to award universities rights that would inhibit professors' ability to

posefully entered into a contract in 1977 [to sell her recipes to Pritikin for a flat fee].").

${ }^{23}$ See Simon, 9 J. Coll. \& Univ. L. at 487 (cited in note 6).

29 See, e.g., 1958 Study at 132 (cited in note 16) (movie industry requested full control over works created by employees); House Comm. on the Judiciary, 88th Cong., 1st Sess., Copyright Law Revision, Part 2: Discussion and Comments on Report of the Register of Copyrights on the General Revision of the U.S. Copyright Law 358-59 (Comm. Print 1963) (comments received from the Motion Picture Assoc. of America, Mar. 2, 1962) ("1962 Discussion").

so See 1 Nimmer on Copyright at $\$ 5.03[\mathrm{~B}][1][\mathrm{b}][\mathrm{i}]$ and $\S 5.03[\mathrm{~B}] \mathrm{n.31}$ (cited in note 5).

s1 See, e.g., Williams, 78 Cal.Rptr. at 546 ("neither the record in this case nor any custom known to us suggests that the university can prescribe [the teacher's] way of expressing the ideas he puts before his students").

32 See generally Princeton Rules (cited in note 9); NYU Handbook (cited in note 9). See also 1 Nimmer on Copyright at $\$ 5.03[B]$ n.31 (cited in note 5).

s3 See generally 1 Nimmer on Copyright $\S 5.03[B]$ (cited in note 5). See also Clarkstown, 566 F.Supp. at 143 n.3 (decided under 1976 Act). 
roam from "campus to campus," disseminating their research. ${ }^{34}$

\section{B. The Copyright Act of 1976}

The Copyright Act of 1976 purports to make little change in the general contours of prior law, but to make more certain the results in particular cases. Under the statute, which treats ownership and authorship separately, the employee's ability to rebut the presumption of employer ownership is sharply curtailed. All work within the scope of employment now constitutes work made for hire, and while the incidents of copyright ownership remain subject to negotiation between employer and employee, only a writing signed by both parties may rebut the presumption in favor of the employer's ownership. Furthermore, authorship of work clearly created within the scope of employment now vests irrebuttably in the employer..$^{35}$

Even though the 1976 Act provides less copyright protection for the full-time creative employee, it extends greater protection to the individual commissioned to create a particular piece of work. Before 1976, courts sometimes treated commissioned work as work made for hire, if this was justified under the totality of the circumstances. The 1976 Act, however, first limits the category of commissioned works that may be considered works made for hire and then provides that courts may regard works within this category as works made for hire only if the employee and employer contracted for this in a signed writing. ${ }^{36}$

These changes could significantly affect the legal status of faculty work product. Scholars have indeed concluded that the

s4 See Williams, 78 Cal.Rptr. at 546 ("No reason has been suggested why a university would want to retain the ownership in a professor's expression. Such retention would be useless except possibly for . . . making it difficult for the teacher to give the same lectures, should he change jobs.").

${ }^{38}$ See 17 U.S.C. $\$ 101$ (1982) (definition of work made for hire includes "a work prepared by an employee within the scope of his or her employment"); 17 U.S.C. $\S 201$ (b) (1982):

In the case of a work made for hire, the employer or other person for whom the work was prepared is considered the author for purposes of this title, and, unless the parties have expressly agreed otherwise in a written instrument signed by them, owns all of the rights comprised in the copyright.

so See 17 U.S.C. $\$ 101$, including in the definition of works made for hire:

a work specially ordered or commissioned for use as a contribution to a collective work, as a part of a motion picture or other audiovisual work, as a translation, as a supplementary work, as a compilation, as an instructional text, as a test, as answer material for a test, or as an atlas, if the parties expressly agree in a written instrument signed by them that the work shall be considered a work made for hire.

See also 1 Nimmer on Copyright $\S 1.06[C]$ (cited in note 5). 
1976 Act abolishes the teacher exception to the work for hire doctrine. They reason that since the 1976 Act suggests that courts should limit their inquiry to the existence of an employment relationship, employees under long-term contracts-such as academics-may no longer argue that the factors surrounding their employment rebut the presumption of employer ownership. Accordingly, the circumstances under which the work was created and the expectations of the parties have now become largely irrelevant. The dispositive issue is whether production of scholarly material is "within the scope of employment," that is, a part of the job. ${ }^{37}$ Since scholarship clearly is a factor in decisions regarding tenure, promotion, salary increases, sabbatical leaves, and reduced teaching loads, ${ }^{38}$ scholarly works should now belong to universities rather than to faculty members.

Nor are professors helped by the provision recognizing written agreements. Since academics' work usually cannot be considered "commissioned" within the provision of the 1976 Act that limits the categories of commissioned work that can be "hired," a signed writing can, at most, have the effect of rebutting the presumption that the employer is the copyright owner. Even with a signed written agreement, authorship remains with the university. In addi-

37 See Simon, 9 J. Coll. \& Univ. L. at 501-09 (cited in note 6); DuBoff, 32 J. Copyright Soc. at 27-34 (cited in note 6).

Interestingly, the courts in many work for hire cases under the 1976 Act have continued to rely on the factors test to decide whether the work at issue was made for hire. See, e.g., Evans Newton, Inc. v. Chicago Systems Software, 793 F.2d 889, 894 (7th Cir. 1986); Aldon Accessories, Ltd. v. Spiegel, Inc., 738 F.2d 548, 552 (2d Cir. 1984); Sygma Photo News, Inc. v. Globe Int'l, Inc., 616 F.Supp. 1153, 1156 (S.D.N.Y. 1985); Iris Arc v. S.S. Sarna, Inc., 229 U.S.P.Q. 25, 27 (E.D.N.Y. 1985); Joseph J. Legat Architects v. United States Development Corp., 625 F.Supp. 293, 297-99 (N.D. III. 1985); Arthur Retlaw \& Associates, Inc. v. Travenol Laboratories, Inc., 582 F.Supp. 1010, 1014 (N.D. Ill. 1984); Sykee v. Roulo, 122 Ill.App.3d 331, 334, 461 N.E.2d 480, $482-83$ (1984).

However, these courts have continued using the factors test only where there was no employment contract or other long-term relationship between the employer and the alleged employee. See, for example, Clarkstown, 566 F.Supp. 137. Where there is such a relationship-as there is in the typical university setting-courts will probably not fall back on the factors test. Accordingly, it is unlikely that the factors test will provide an opportunity for professors to incorporate the "teacher exception" into the 1976 Act. But see Weinstein v. University of Illinois, 811 F.2d 1091 (7th Cir. 1987) (Easterbrook) (rejecting the university's argument that it owns the copyright to work prepared by an academic in the course of employment and with university funding). Furthermore, Congress is currently considering a bill that would, among other things, largely eliminate use of the factors test. See S.2330, 99th Cong., 2d Sess., in 132 Cong. Rec. S4493-94 (Apr. 17, 1986) (remarks of Senator Cochran).

so See, e.g., Michael I. Swygert and Nathaniel E. Gozansky, Senior Law Faculty Publication Study: Comparisons of Law School Productivity, 35 J. Legal Educ. 373, 374 nn. 4, 6 (1985), and authorities cited therein. 
tion, while many faculty handbooks announce policies favoring faculty retention of copyright, handbooks are unlikely to be considered signed writings within the meaning of the Act.

\section{Constitutional Challenges to the 1976 Act Provisions}

Academics could claim that the work for hire provisions of the 1976 Act are unconstitutional under both the first amendment and the copyright clause. Although both arguments would add ballast to the idea that the work for hire doctrine has been wrongly interpreted as applied to academic materials, neither is likely to be successful, especially if brought as facial challenges to the Act.

1. First amendment. Academics might argue that their freedom to speak will be impermissibly chilled if universities are deemed the owners of faculty scholarship. This argument, however, is likely to be poorly received by the courts. First, control over work does not, of itself, limit an academic's prerogatives to continue to set down her thoughts or to speak out. While the university's legal rights may interfere with utilization of previously completed works, the Copyright Act has been created and interpreted to take account of the free speech interests in using protected works. ${ }^{39}$ Except that the party presenting the first amendment

s9 See, e.g., 17 U.S.C. § 102 (b) (withholding copyright protection for ideas) and id. $\S 107$ (permitting certain unauthorized, socially productive uses of protected works); United States v. Bodin, 375 F.Supp. 1265, 1267 (W.D. Okla. 1974), cited with approval in Zacchini v. Scripps-Howard Broadcasting Co., 433 U.S. 562, 577 n.13 (1977) (rejecting argument that copyright is a restraint on free speech on the ground that "no restraint [has been] placed on the use of an idea or concept"). See also Melville B. Nimmer, Does Copyright Abridge the First Amendment Guarantees of Free Speech and Press?, 17 U.C.L.A. L. Rev. 1180 (1970); Paul Goldstein, Preempted State Doctrines, Involuntary Transfers and Compulsory Licenses: Testing the Limits of Copyright, 24 U.C.L.A. L. Rev. 1107, 1124 (1977) (arguing that even if the Soviet Union were able to acquire copyrights to dissidents' work, it could not suppress the flow of their ideas).

This is not to deny that some cases will be difficult to decide. Factual works raise particularly hard questions because courts are reluctant to deny copyright protection to factual works that represent a large expenditure of resources, even when they consist mostly of facts or ideas. See, e.g., Sheldon v. Metro-Goldwyn Pictures Corporation, 81 F.2d 49, 54-55 (2d Cir. 1936); Gary L. Francione, Facing The Nation: The Standards for Copyright, Infringement, and Fair Use of Factual Works, 134 U. Pa. L. Rev. 519, 540-43 (1986). But this difficulty is endemic to copyright law in general; it is not a function of the work for hire doctrine.

Of course, it could be argued that some ideas are most forcefully expressed with a particular expression. In that case, the expression may be found uncopyrightable (leaving the academic free to use it), or the academic's use may be considered a "fair" one under 17 U.S.C. $\$ 107$. A professor may be able to carry the argument one step further and claim that although her ideas could be expressed in a variety of ways, she should not be prevented from using the expression most felicitous to her and that if her university owns that specific expression, her ability to speak has been restricted. But see Dodd, Mead \& Co. v. Lilienthal, 
claim is the natural creator of the work, the argument that a faculty member would be inhibited in further use of her output differs little from any claim that the ownership of a copyright infringes on the free speech of those who cannot use the expression without permission. Such arguments rarely succeed, because courts defer to Congress's judgment concerning the appropriate balance between the free flow of ideas and information and the need to promote investment in creativity. ${ }^{40}$ The effect of the employment agreement is conceptually similar to agreements of confidentiality, which courts generally uphold even though they may stifle the speech of one of the parties. ${ }^{11}$

A more serious charge is that since the university would, under this interpretation of the statute, automatically own all the scholarship created by a faculty member during the entire term of employment, ${ }^{42}$ there is a real danger that it could significantly interfere with adequate dissemination of all her research and ideas. If, for example, the university considered dissemination in conflict with its economic interests, it could use ownership of the copyright to suppress publication of the academic's work entirely. The forced silence, condoned by the federal act, may well run counter to the academic's first amendment rights.

But even here, it is unlikely that the statute would be held invalid on its face. Scholars retain complete control over all speech unrelated to their work, and the more clearly extracurricular the work is, the less danger that the work for hire doctrine rules would be triggered at all. Of course, difficult questions will arise in this

514 F.Supp. 105 (S.D.N.Y. 1981) (refusing to find first amendment problem when publisher refused to circulate plaintiff's book, and finding plaintiff's attempts to publish it an infringement of the publisher's copyright).

to See Hearst Corp. v. Stark, 230 U.S.P.Q. 401, $406-07$ (N.D. Cal. 1986) ("This court has been unable to find any case in which the U.S. Supreme Court, or indeed any other federal court, has invalidated any section of the Copyright Act on First Amendment grounds."). The Hearst court upheld 17 U.S.C. $\$ 602$ (1982), which barred importation of infringing works, against a challenge that the statute abridged free speech when applied to importation of books that were not available in the United States. See also Authors League of America, Inc., v. Oman, 790 F.2d 220, 222-23 (2d Cir. 1986) (upholding manufacturing clause of Copyright Act, 17 U.S.C. $\$ 601$ (1985), which restricts the importation of copyrighted, foreign-manufactured, nondramatic, literary works, against the claim that the clause chilled first amendment rights to distribute and circulate ideas). Even in cases where transfers of copyright do inhibit later work by the same author, the transfer is usually enforced. See, e.g., Gross v. Seligman, 212 F. 930 (2d Cir. 1914).

1 See, e.g., Snepp v. United States, 444 U.S. 507 (1980) (per curiam) (confidentiality agreement signed by CIA employee); Carpenter Foundation v. Oakes, 26 Cal.App.3d 784, 792-93, 103 Cal.Rptr. 368, 373-74 (1972) (injunction not a violation of first amendment when based on breach of "contractual relationship and one of trust and confidence").

12 In the case of tenured faculty, this could be an entire lifetime. 
context. Because faculty generate their own research agendas, work away from their offices, and fail to keep regular hours, decisions as to whether a particular work was completed within the scope of employment will sometimes be extraordinarily difficult. But this difficulty does not imply that the statute is unconstitutional. Were there a serious instance of suppression-if a university refused, for example, to allow a faculty member to take a controversial or unpopular stand-the provisions could be declared unconstitutional as applied to the facts of that case. ${ }^{43}$ Nonetheless, the fact that academic life does not lend itself to the kind of analysis intended by the statute suggests that it may, indeed, be wrong to apply the statute to academics. This conclusion will be reinforced through further examination of the work for hire doctrine on the creative environment.

2. Copyright clause. Professors also might attack the post1976 work for hire provision on the ground that it violates the copyright clause. They could argue that Congress exceeded its authority by granting exclusive rights to employers who have not themselves fulfilled the constitutional purpose of enlarging the pool of knowledge. Judge Friendly made a similar point in his dissent in Scherr v. Universal Match Co., in which the majority found that a statue created by servicemen at an army base was made for hire. Judge Friendly took issue with the notion that Congress has the constitutional authority to promulgate a per se rule deeming every employer the "author" of his employee's creations:

the Constitution, Art. I, $\S 8$, authorizes only the enactment of legislation securing "authors" the exclusive right to their writings. It would thus be quite doubtful that Congress could grant employers the exclusive right to the writings of employees regardless of the circumstances.

Judge Friendly acknowledged that in cases in which "the employer in fact tells the employee pretty much what to do, vesting copyright in the former is wholly consistent with the policy of the Copyright Act since the creativity can be said to be primarily the employer's." However, he indicated that in some cases the locus of activity might remain so exclusively with the employee that to define the employer as the author for copyright purposes would ex-

${ }^{43}$ It is interesting to note that constitutional challenges apparently have not arisen in connection with the traditional policy of university ownership of student dissertations, even though universities maintain strict policies on the timing of their publication. See John C. Hogan and Saul Cohen, An Author's Guide to Scholarly Publishing and the Law 3-5 (1965). 
ceed Congress's powers under the copyright clause. ${ }^{44}$.

According to Judge Friendly's formulation, then, the post-1976 work for hire doctrine would be unconstitutional as applied to academics if universities were so far removed from the professors' creative processes that the universities could not be deemed "authors" in the constitutional sense. And indeed, professors are certainly more than mere scriveners who carry out plans laid down by their universities. In general, academics themselves select their research goals, procure their own funding, determine their research strategy, and choose the format through which their findings are expressed. Thus, the university is rarely the "genesis of the ideas memorialized in the work," 45 and it is only sometimes the entrepreneur underwriting its production. It is hard to think of a setting in which employer authorship is more of a legal fiction.

As Professor Melville Nimmer has pointed out, however, this argument, by focusing solely on the semantic classification of a party as an "author," takes a rather literal view of the structure and the operation of the 1976 Act. ${ }^{46}$ The Act has two effects. First, it creates a presumption in favor of copyright ownership. Second, it creates a rule about authorship. Since the Act permits employees to negotiate the issue of copyright ownership and to rebut the presumption in favor of the employer, it does not exceed Congress's constitutional authority. That is, Congress has the authority to decide that it is more likely than not that the parties have agreed to the employer's ownership of the copyright, or that important social policies are advanced if copyright is used to encourage the behavior of employers. ${ }^{47}$ With regard to authorship, the Act does irrebut-

4Scherr, 417 F.2d at 502 (Friendly, dissenting).

${ }^{45}$ Clarkstown, 566 F.Supp. at 141-42.

4 See 1 Nimmer on Copyright at $\$ 1.06$ [c] (cited in note 5).

47 See Edward G. Cleary, ed., McCormick on Evidence 969 (3d ed. 1984) ("[m]ost presumptions have come into existence primarily because [1] the judges have believed that proof of fact $B$ renders the inference of the existence of fact $A$ so probable that it is sensible and timesaving to assume the truth of fact A until the adversary disproves it," or because [2] the presumption will advance social policies) (footnote omitted).

It may be somewhat suspicious that this statutory presumption allows rebuttal with only one form of proof, namely a signed writing. Although civil presumptions have not been accorded the same degree of scrutiny as criminal presumptions, see McCormick on Evidence at 985 , this provision is nevertheless unsettling. The legislators who revised the Act seem to have relied heavily on the notion that since an employee can bargain for the right to retain copyright, a lack of written documentation must mean that the employer owns the copyright. This assumption is tenuous at best. Because the work for hire provision is somewhat counterintuitive, employees may be unaware of the draconian consequences of failing to obtain a signed document. Furthermore, if the value in owning the copyright lacks a pecuniary dimension, the employee may not have sufficient financial expectations to buy the rights to the work. 
tably transfer authorship from the employee to the employer. According to Professor Nimmer, however, this transfer merely alters certain incidents of copyright ownership-rules governing the du'ration of the copyright ${ }^{48}$ and the right to terminate the grant.48 In Nimmer's view, Congress surely had the constitutional authority to treat works for hire differently from other works with respect to these matters, for it could reasonably believe that some of the benefits available under the Act should be altered if a work was created pursuant to an employment relationship rather than "on speculation." That Congress chose to accomplish this goal by deeming employers the authors of their employees' creations is unremarkable. ${ }^{\text {so }}$

Nimmer may have explained why Congress may constitutionally shift the benefits of authorship from a creator to her employer. But his argument focuses on differences in the duration and termination of copyright-rules that deal mainly with the question of who gets how much for how long. In doing so, he seemingly assumes that financial considerations are the only ones that count. But furthering the constitutional goal requires more than a focus on the purely remunerative components of copyright ownership. As we shall see, the concerns that flow from an intellectual commitment range far beyond the purely financial and may have only a fragile connection to economic expectations. As a result, creative employees may be unable to purchase the right to protect themselves, and the initial assignment of rights to employers may not be so easily circumvented as the drafters of the 1976 Act appeared to believe.

While the following examination of the work for hire doctrine in the collegial setting may not amount to a constitutional attack, it is useful to examine the changes that would occur in the creative

13 Section 302 of the 1976 Act provides that copyright subsists for the life of the author and for 50 years after the author's death. Copyright in works for hire, however, endures for 75 years from the year of publication or 100 years from the year of creation, whichever expires first. For the incidental effects of the work for hire provisions, see 1 Nimmer on Copyright at $\$ 5.03$ [A] (cited in note 5).

49 Section 203 of the 1976 Act allows natural authors to terminate grants of transfers and licenses, but this provision does not apply to works made for hire.

${ }^{80} 1$ Nimmer on Copyright at $\$ 1.06[\mathrm{C}]$ (cited in note 5). Alternatively, it could be argued that since the philosophy underlying the copyright clause is to "encourag[e] individual effort by personal gain," Mazer v. Stein, 347 U.S. 201, 219 (1954), Congress could promote the purposes of the clause by giving the right to the gain to the creator himself or to the party who directs the creator and pays his salary. Either way, financial reward is used to motivate creative effort; nothing in the copyright clause requires that the financial rewards flow directly to the creator from the end-user. 
environment as a result of deeming the university the author of faculty work product. First, the magnitude of the distortions may cast doubt on commentators' conclusions that the work for hire doctrine should be so interpreted. Second, the alterations should serve as a warning to those institutions that may be contemplating a requirement that some or all of their faculties assign their copyrights to the university. More fundamentally, however, this investigation is a means for testing the hypothesis that current copyright law offers protection to authors' nonpecuniary interests. Through the (perhaps) fortuitous overlap of financial and other concerns, federal law has already turned from a focus solely on public access and has adopted a somewhat author-based approach to copyright. Once this is recognized, it may be easier to discern a need to address more systematically the needs of authors within the federal framework.

\section{The Influence of Copyright on the Creative Environment}

I will argue that the influence of copyright on the creative employee cannot be understood without an appreciation of the nonpecuniary interests that are at stake in the creative process. As I will show, creators have three central nonpecuniary interests in their works: first, a possessory interest, which is fulfilled by composing a work that satisfies the creator's initial vision; second, an interest in the integrity of the work, which is endangered by the process of compromising that vision with commercial demands; and third, a reputational interest, which turns on how the work is presented to the public.

Society as a whole shares the same cluster of concerns with regard to creative works. High-quality work enriches the cultural heritage; thus it is important to allow and encourage someone with expertise, and an understanding of the vision underlying the work, to protect its integrity. Even if the public is unable to appreciate a creator's work at the time of its creation, knowledge will advance more rapidly if the creator is permitted to pursue interests at the leading edge of his field. If creators are allowed to resist compromising their conceptions to meet popular demand, pioneering efforts often will endure until the time when their contribution can be appreciated. ${ }^{\mathrm{BI}}$ Since reputations serve signaling functions that

${ }^{51}$ See Roberta Kwall, Copyright and the Moral Right: Is an American Marriage Possible?, 38 Vand. L. Rev. 1, 93 (1985). The works of avant garde musicians and of writers such as James Joyce are examples of material that the public does not currently understand, but may grow to appreciate as taste in music and literature is changed by less advanced artists. 
reduce the social costs of searching for, and sifting through, information, the public benefits from the creator's ability to protect his standing in his field and the character of his work. Similarly, the ability to control attribution diminishes the transaction costs involved in disseminating the ideas of society's most talented individuals. In addition, it is largely by knowing to whom to attribute inferior (and superior) work that society motivates creators to do their best. ${ }^{.22}$

These interests are implicated in the judgments that are made as ideas are conceived, brought to fruition, disseminated, and used. ${ }^{53}$ Each stage in the creative cycle is marked by tension between the internal needs of the creative intellect and the demands of the public. While an analysis of each situation focusing purely on pecuniary interests appears to demonstrate that public access is not reduced, and may even be enlarged, by placing the right of exploitation in the hands of employers who are more closely attuned to public demand, an author-based approach discloses a host of secondary effects that severely alter the picture.

Thus, it is only when financial and creative interests converge that superior decisions are made at each of the four stages examined. Pecuniary considerations play a complex role in shaping the creative output. If the copyright mechanism is fully controlled (at least initially) by the party who best understands the work, the creator's expertise, vision, and self-interest are enlisted in maintaining the cultural heritage. Severing financial considerations from other creative concerns harms not only the interests of authors in the integrity of their work and in their reputation, but those of the public in high-quality, accessible, creative material.

\section{A. Conceptualization}

As soon as I had begun this work [painting the vault of the Sistine Chapel] I realized that it would be but a poor thing, and I told the Pope how, in my opinion, the placing of the

${ }^{82}$ See, e.g., The Economist 97 (Feb. 28, 1987) (noting explosion in the number of scientific journals and arguing that the growth in scientific fraud is due to the increased practice of multiple authorship, which makes attribution of errors impossible, and to the pressure to publish a large quantity of papers rather than high-quality papers).

ss Division of the creative cycle into four parts is both artificial and misleading. In fact, the stages are interdependent: at the conceptualization phase, for example, a creator may select a particular project because the creator estimates that the project's end product will be easily distributed. Nonetheless, the division facilitates an examination of the dynamics of the creative process. 
Apostles there alone would have a very poor effect. He asked why, and I replied, "Because they also were poor." He then gave me fresh instructions, which left me free to do as I thought best. ${ }^{54}$

Conceptualization is the process of putting the creative cycle into motion, of choosing a project to which intellectual resources will be allocated. It begins when the creator decides whether she should create anything at all, progresses to her selection of a specific project, and then moves on to an array of more subtle choices: what kind of work to create, ${ }^{55}$ tailored to which audience, ${ }^{56}$ pitched at what level of discourse. ${ }^{57}$

A host of influences operate on the creator at this stage. She starts with certain innate abilities, ${ }^{88}$ a need to communicate and to be recognized, ${ }^{69}$ as well as a desire to contribute to the cultural heritage. The direction taken by the confluence of these abilities and desires is a function of the creator's aesthetic sense, ${ }^{60}$ as well

s4 Letter from Michelangelo to Ser Giovan Francesco Fattucci, January 1524, reprinted in Robert Goldwater and Marco Treves, eds., Artists on Art 61-62 (1945).

ss See Albert Einstein, Message to the Italian Society for the Advancement of Science, reprinted in Albert Einstein, Ideas and Opinions 356-59 (1954) (speaking of the need to choose between theoretical and practical research objectives).

se See, e.g., the remarks by dance critic Anna Kisselgoff, in Stanley Rosner and Lawrence Abt, eds., The Creative Expression 159 (1976): "I wrote a more scholarly piece recently in a university journal on a choreographer in a way that I could not write in the Times."

${ }^{s 7}$ See, e.g., Mark Tushnet, Legal Scholarship: Its Causes and Cure, 90 Yale L. J. 1205, 1208 (1981), discussing different types of legal scholarship.

ss See, e.g., D.W. MacKinnon, The Personality Correlates of Creativity: A Study of American Architects, in Phillip Ewart Vernon, ed., Creativity: Selective Readings 289-311 (1970) (citing orderliness, perceptiveness, skepticism, and personal awareness as personality traits that are conducive to creativity in architecture). See also Augusto Centeno, ed., The Intent of the Artist 7 (1941) ("[T]he artist is the man so endowed as to feel, think, and act in a manner that leads inexorably to the creation of a work of art, and in such a way that were he deprived of every opportunity for artistic creation, his life would become an acute misery.").

So, Se.g., the remarks by Jean-Paul Sartre, Being and Nothingness, excerpted in Robert Cumming, ed., The Philosophy of Jean-Paul Sartre 306-07 (1965) ("It is in order to enter into this double relation in the synthesis of appropriation that I create my work. . . . It is through me that a facet of the world is revealed; it is to me that it reveals itself. In this sense I am creator and possessor."). See also Paul A. Samuelson, On the Prowl in an Enchanted Forest, N.Y. Times $\S 2$ at 2, col. 5-6 (Oct. 12, 1986) ("Scientists are as avaricious and competitive as Smithian businessmen. The coin they seek is not apples, nuts and yachts; nor is it coin itself. . . . Scholars seek fame.").

- See, e.g., James Joyce, A Portrait of the Artist as a Young Man 215 (Penguin ed. 1964):

The personality of the artist, at first a cry or a cadence or a mood and then a fluid and lambent narrative, finally refines itself out of existence, impersonalises itself, so to speak. The esthetic image in the dramatic form is life purified in and reprojected from 
as her formal training, personal values, ${ }^{61}$ and the pressures and opportunities within the cultural milieu. ${ }^{62}$

While there is a substantial degree of randomness to conceptualization $^{83}$ that makes generalizations difficult, creators appear to agree that the conceptualization process is intensely personal and largely self-generating. ${ }^{64}$ Many creators claim (as did Michelangelo) that the value in their work depends entirely on its fidelity to their inner vision. Isaac Bashevis Singer put it this way:

Before I sit down to write a story, I must have the conviction that only I can write this particular story. . . . Many writers will get a topic and they will write about something which any other writer, or some other writer could write. When we see the great works in literature, we know that they were all completely unique. ${ }^{6 s}$

For many creators, the conceptualization process must not only be intensely personal, but also deliberately antisocial. These

the human imagination. The mystery of esthetic like that of material creation is accomplished. The artist, like the God of creation, remains within or behind or beyond or above his handiwork, invisible, refined out of existence, indifferent, paring his fingernails.

61 See id. at 246-47:

Look here, Cranly, he said. You have asked me what I would do and what I would not do. . . . I will not serve that in which I no longer believe whether it call itself my home, my fatherland or my church: and I will try to express myself in some mode of life or art as freely as I can and as wholly as I can.

See also Copyright Law Revision Hearings on S.597, before the Subcomm. on Patents, Trademarks, and Copyrights of the Senate Comm. on the Judiciary, 90th Cong., 1st Sess. 910 (1967) (statement of John C. Stedman, American Association of University Professors) (noting public purpose motivating educational writings).

${ }_{62}$ See, e.g., OTA Report at $49-53$ (cited in note 12) (cultures advance as creative individuals apply their abilities to improve and utilize what has been created before them); id. at 150-51 (describing how technological developments, such as computer graphics, furnish new creative opportunities).

${ }^{63}$ See, e.g., F. M. Scherer, Industrial Market Structure and Economic Performance 412 (2d ed. 1980).

${ }^{64}$ See Alfeo Faggi, The Sculptor, in Robert Heywood, ed., The Works of the Mind 39, 46-48 (1966) (describing creative artist's inner compulsion to create what he has imagined in whatever medium most appeals to his sensitivities).

${ }^{6 s}$ Stanley Rosner and Lawrence Abt, eds., The Creative Experience 228-29 (1970) (remarks by Isaac Bashevis Singer). See also Sherwood Anderson, Man and his Imagination, in Centeno, The Intent of the Artist at 45 (cited in note 58) ("There is the obligation to himself, to his own imagination, its growth.").

These artists are not talking about censorship or state control of their work, a problem that is beyond the scope of this article. Rather, the point here is that even without overt control, external pressures can be destructive to the quality of the work that emerges. See generally Albert Guerard, Art for Art's Sake 176-97 (1936) (arguing that censorship, state regulation, prizes, and honors are all points on the spectrum of external control). 
creators not only agree with Singer that the integrity of their work depends on their faithfulness to their own artistic conceptions, ${ }^{68}$ but they also claim that defying social expectations is an important ingredient of their creativity. Thus, they purposely design works that are disturbing to society and difficult to understand. The consensus seems to be, then, that-at least at the highly innovative end of the creative spectrum-creators regard the taste and demands of the public as largely irrelevant to their decisions. ${ }^{67}$ If "profit" is defined in purely pecuniary terms, the highly creative may be profit seekers, but they are not all profit maximizers.

If this is the case, the effect of shifting copyright ownership in the employment context would appear to depend on whether the employer shares the creative employee's indifference to public demand. If the employer is willing to defer to his employees all decisions relative to the employees' work, then the character of the material produced may remain relatively constant. If, however, the employees' and the employer's motivations diverge, output will change. ${ }^{68}$ Universities could, for example, fully exploit their control over faculty by using the relevance of scholarship to the granting of tenure, promotions, salary increases, and the like to skew the

${ }^{68}$ See, e.g., Van Gelder, Writers and Writing at 43 (cited in note 12) (describing Katherine Anne Porter's refusal to seek advice on her work so that it would remain "entirely [her] own"); id. at 265 (noting that according to Louis Bromfield, "the quality that a writer needs beyond any other is independence"); Rosner and Abt, eds., The Creative Experience at 277 (cited in note 65) (remarks of Aaron Copland) ("You have a sense of urgency, of being occupied with something essential and unique. To leave our mark of the present on the future-what could be more natural?").

77 See, e.g., Robert Pinsky, Control Freedom and the Appetite for Poetry, 52 Triquarterly 197, 199 (1981) ("my main response to the idea of control is that it is something external, from which the artist profits by resisting"); Guerard, Art for Art's Sake at 128 (cited in note 65), where, in discussing Oscar Wilde's disdain of popularity, Guerard writes, "[T]o have articles, books, bibliographies, iconographies and doctoral dissertations composed about you; . . . this is fame indeed: but is it Art?"; Anderson, Man and his Imagination, in Centeno, The Intent of the Artist at 47 (cited in note 58) ("They tell us we are torchbearers, preservers of the culture of the people, etc. A man is likely to get that sort of thing up into his own head and it separates him from others. It is like giving a man the Nobel Prize or something of that sort. It should never be done to a man until he is old and feeble-until his usefulness is gone."); Letter from Sinclair Lewis to the Pulitzer Prize Committee, reprinted in Harry E. Maule and Melville H. Cane, eds., The Man from Mainstreet: A Sinclair Lewis Reader 19 (1953) ("All prizes, like all titles, are dangerous. The seekers for prizes tend to labor not for inherent excellence but for alien rewards: they tend to write this, or timorously to avoid writing that, in order to tickle the prejudices of a haphazard committee.").

os An employer who is a profit maximizer may nonetheless decide that the best strategy for maximizing return is to give employees creative control. In that event, the quality of the output may not change. However, for reasons explained in part III-A, it is unlikely that a rational employer would believe that this strategy would produce maximum pecuniary gain. 
faculty's conceptualization decisions in favor of the most economically remunerative projects. In consequence, even professors who share the willingness of other creative individuals to ignore public demand could find themselves forced to use the potential for financial reward as the main criterion for choosing assignments.

The issue, then, is whether this change would lead to more or less socially productive use of academic talent. From an economic standpoint, it is tempting to argue that this change would be socially desirable. After all, if the employer is more sensitive to pecuniary possibilities than the employee, his influence on conceptualization decisions should force employees to produce more works in which the public has demonstrated its interest. That is, since users generally choose to pay only for works that they regard as useful, and then only up to the price that fully reflects a work's utility, the aggregate payments of all buyers quantify the utility generated by the work. ${ }^{69}$ If employers allocate resources by reference to profit exclusively, then they will choose to produce that mix of works in which the public's interest appears to be greatest. ${ }^{70}$

The author-based approach reveals the fallacy of this reasoning. Close attention to popular taste often can inhibit creativity as the author searches for the least common denominator that appeals to the greatest numbers, or shies away from controversial topics. Professor Sidney Hook writes:

When I was younger, I used to get off some striking expressions, but as I've gotten older and acquired hosts of antagonists . . . who seem ready to pounce upon any seeming mistake or misinterpretation, I became more guarded, and I feel today more cramped. . . . Of course, try as you will, you can't

69 For a related discussion, see Wendy G. Gordon, Fair Use as Market Failure: A Structural and Economic Analysis of the Betamax Case and its Predecessors, 82 Colum. L. Rev. $1600,1605-13$ (1982).

Note that public interest should not be equated with social value. For various reasons, which are discussed below at notes $129-40$ and accompanying text, copyright fails fully to capture social value.

${ }^{70}$ Of course, academics always have been influenced by their universities. See, e.g., EImer Davis, Writing and the Butcher's Bill, in Norman Cousins, ed., Writing for Love or Money 28, 30-31 (1949) (describing the pressure to "spend the summer annotating the novels of some forgotten writer of the past" rather than writing a novel of his own). In the past, however, universities and academics differed on what scholarship. The current interest in copyrights suggests that the fight will now be about whether scholarship.

This is not to say that universities are necessarily incapable of perceiving the benefits that accrue from ground-breaking work that is not highly valued by the market. Since universities' reputations often turn on such work, they too may not be "profit maximizers" in the purely financial sense. The social consequences of copyright transfer in such situations are described below. 
safeguard yourself against the will to misunderstand. But the effort to do so makes you much more cautious. . . . I still haven't got the true artist's creative feeling of "what the hell, let them think what they want; I know what I mean." "71

Furthermore, deploying creative talent among alternative projects is difficult. It requires an understanding of the available alternatives, an appreciation of the creator's abilities, and the capacity to judge whether creativity will continue to flourish under the demands of the project that has been chosen. In the classic employment situation, the employer may well possess the qualities necessary to make the best use of employees' creative abilities. The factors examined by the courts under the 1909 Act were essentially proxies for the skills necessary to exploit talent productively; and while the 1976 Act largely has abandoned the factors test, the employment contract often will provide an adequate substitute.

But the new Act is problematic insofar as it permits work to be considered made for hire in contexts far removed from Judge Friendly's paradigm of the employer who "tells the employee pretty much what to do." It is unlikely that "noncreative" employers have the capacity to make the right choices regarding the application of the talents of creative employees, especially with respect to work at the forefront of its field, where results are not predictable. Where ground-breaking scholarship is at issue, it is difficult to see how an administrator could acquire the competence necessary to weigh the risks involved in choosing one project over another, appreciate the difficulties that will arise in pursuing the ultimate objectives, and, in the end, allocate the resources of the faculty better than-or even as well as-the faculty members could do themselves. To the extent that administrative decisions will differ from those that the faculty would make, first amendment values may be impinged, if not violated.

7 Rosner and Abt, eds., The Creative Experience at 299 (cited in note 65) (remarks of Sidney Hook).

Some creative individuals admit that it is possible to tailor their work to the needs of others and remain creative. See, for example, Paul Cummings, Artists in Their Own Words: Interviews with Paul Cummings 116 (1979) (remarks by sculptor and theatrical set designer Isamu Noguchi) ("I prefer to have requirements in a sense. If I'm left completely alone, I'm a little bit at sea. I enjoy a problem."); Rosner and Abt, The Creative Expression at 68-69 (cited in note 56) (remarks by illustrator Arthur Getz) (describing the process of creating a New Yorker cover). See also The Curious Retirement of Mr. Hergesheimer, in Van Gelder, Writers and Writing at 149,150 (cited in note 12) (arguing that it is possible to make compromises and stay true to artistic conception); Rosner and Abt, The Creative Experience at 274 (cited in note 65) (remarks by Aaron Copland) ("You can force yourself to think, and then, suddenly, you find you've forgotten that you began by forcing yourself."). 
It is, of course, unlikely that universities will begin to direct academic research, or even to assert copyright ownership over their faculties' entire output. Indeed, in instances where institutions have actually claimed ownership of faculty work product, they have asserted their interests only after the work was produced and in general have limited their claims to the rights to remunerative material such as software. ${ }^{72}$

But even if universities remain passive and selective, distortions in output are likely to occur. An individual who stands to enjoy all the benefits of every project on which he works has every incentive to devote his energies to the ones that best accommodate the tension between personal vision and the desire to communicate: he is, in a sense, vested with the power to allocate a social resource (his talents) to the project that represents the best use of that resource. But the creator is not encouraged to try to make the most socially productive choice when the benefits of choosing to work on some projects vest in the employer, while the benefits of working on other projects vest in the individual. ${ }^{73}$ If universities assert their statutory right to copyright only in certain circumstances, faculty members will be likely to choose not to work on the type of projects in which their universities are likely to claim an interest, regardless of whether those projects are the ones that optimize the use of their talents. ${ }^{74}$

72 See, e.g., Princeton Rules at 103 (cited in note 9) (asserting copyright to computer programs); Robert D. Varrin and Diane S. Kukich, Guidelines for Industry-Sponsored Research at Universities, 227 Sci. 385, 386 (1985) (suggesting universities adopt copyright policies for software); Simon, 9 J. Coll. \& Univ. L. at 507 (cited in note 6) (citing instructional works as an especially lucrative area). See generally Breyer, 84 Harv, L. Rev. 281 (cited in note 2) (suggesting that the economics of publishing textbooks is significantly different from other works). Stanford University, to cite one example, has enjoyed considerable success licensing a software chip for the design of music synthesizers invented by music professor John Chowning. See Lepkowski, Chem. \& Engin. News 23 (Nov. 23, 1981) (cited in note 7).

${ }^{73}$ The likes of Carolyn Heilbrun may choose to produce Kate Fansler mysteries (which presumably do not fall within the scope of her employment as an English professor at Columbia University) instead of contributing monographs to Columbia University Press's series of essays on modern writers. Compare Amanda Cross, Poetic Justice (1970) with Carolyn G. Heilbrun, Christopher Isherwood (1970).

${ }^{74}$ Another argument advanced for divesting professors of the financial gain in their work product is that this will "keep the professor 'honest.' " See John Seile Brubacher, Bases for Policy in Higher Education 84 (1965), which suggests this as the reason that the University of Chicago at one time demanded the copyrights in its faculty's work. It is difficult to discern precisely what Brubacher means. He is either claiming that the financial opportunities available to professors will taint their scholarship, or that faculty who spend time on remunerative work are not fulfilling the scholarly function of the university. The latter claim is particularly difficult to understand. Although section III-A suggests reasons why the market may not fully reflect the social utility of scholarly output, the opposite conclusion-that scholarship is not socially useful if it is remunerative-does not follow. 
Transferring copyright from professors to universities might hamper the public's interest in increased creativity in yet another way. The creator's prerogative not to begin a work or to let an idea gestate for a number of years may be necessary for the optimal functioning of the creative process at the conceptualization phase. These fallow periods may serve as opportunities to store experiences and to engage in a form of undirected research, and thus may lead to more creative work than would have developed had the creator been forced to produce on an externally imposed, accelerated schedule. ${ }^{78}$ These periods are not necessarily socially unproductive. In a collegial setting such as a university, fallow episodes also may signify periods in which the individual is contributing to the creativity of others by advising younger colleagues, commenting on the work of others, lecturing, or, more prosaically, taking over administrative functions to release others for scholarly work. ${ }^{76}$ In addition, these periods allow a scholar to use publication as a signal to colleagues that the scholar's material is now worth reading. For example, a study of Nobel laureates reveals that they often make conscious decisions not to publish work that "could easily find its way into print." Work that is produced is then taken

Moreover, the work for hire doctrine is poorly suited to police academics' devotion to their jobs, since the work that most clearly diverges from the university's mission would most likely escape university claims of authorship on the ground that it is outside "the scope of employment" within the meaning of 17 U.S.C. $\$ 101$.

Brubacher's other argument, that professors may slant their results to suit the paying audience, is more troublesome, but it is hard to make in this context. Because administrators' reputations turn, in part, on the financial bottom line of their institutions, they would be more tempted than academics to compromise results to achieve financial gain. A professor's reputation depends, in the end, on the thoughtfulness and truthfulness of her scholarship. Indeed, the concepts of tenure and academic freedom were institutionalized precisely because it was thought that knowledge would be better advanced if faculty were in control of what they said and published. See Hogan and Cohen, Author's Guide at 98-102 (cited in note 43) (discussing the significance of academic freedom and tenure). Furthermore, the close connection between faculty and industry has been cited as one of the reasons that American universities are more innovative than their Japanese counterparts, where faculty are isolated from "the dynamic mainstream of [research and development]." Eliot Marshall, School Reformers Aim at Creativity, 233 Sci. 267, 269 (1986).

${ }^{7 s}$ See Barbara J. Culliton, NIH Proposes Extending Life of Grants, 226 Sci. 1400 (1984) (discussing wisdom of extending length of National Institute of Health research grants in order to allow grant holders to do "exploratory" rather than "exploitative" research.

76 Consider David Kaye and Ira Ellman, The Pitfalls of Empirical Research: Studying Faculty Publication Studies, 36 J. Legal Educ. 24, 25-26 (1986), refuting Swygert and Gozansky's thesis that failure to publish signifies "an underutilization of intellectual resources." Kaye and Ellman argue that lack of publication simply may indicate that the academic's talent is being channelled into other, equally productive activities. 
seriously, which, in turn, enhances its heuristic impact. ${ }^{77}$ Aside from this signaling function, fallowness-or selectivity-prunes the work in the scholar's field to more manageable proportions, which gives others less to sort through and makes knowledge more accessible. ${ }^{78}$

Universities that benefit from the copyright to faculty work might, however, be tempted to prevent the creative professor from undertaking fallow periods. If less work is produced, there is less to sell. ${ }^{79}$ Furthermore, regular contribution to a field builds a following-a market - that may not develop if there are long periods between publications. ${ }^{80}$ Thus, the creative benefits of these seemingly unproductive periods may disappear if the copyrights of scholars' works-and thus incentives to control the works themselves-are given to universities.

\section{B. Fruition}

I write the first time to please myself. I put in everything that I think of. I am a contented writer who can write all day and be happy. So the early drafts of my books are very, very long.

On the other hand, I am a nervous reader. I become very impatient when any author-including myself-strays from his point. So when I read what I have written I cut it in great chunks. I chop and chop until there is not a spare word, a

77 Robert Merton, The Matthew Effect in Science, 159 Sci. 56, 61 (1968) ("Since they prefer their published work to be significant and fruitful rather than merely extensive, their contributions are apt to matter. This in turn reinforces the expectations of their fellow scientists that what these eminent scientists publish . . . will be worth close attention."). See also Richard A. Posner, Privacy, Secrecy and Reputation, 28 Buffalo L. Rev. 1, 14 (1979) (privacy protection "serves, paradoxically, ... the function of promoting rather than impeding the flow of accurate information" because it allows a person to edit the thoughts that become public).

${ }^{78}$ Compare George Stigler, An Introduction to Privacy in Economics and Politics, $9 \mathrm{~J}$. Legal Stud. 623, 640-41 (1980) (arguing that since the cost of disseminating information can be greater than the cost of developing it, more attention should be paid to facilitating efficient distribution).

79 For example, in describing the negative features of writing for a magazine, Elmer Davis said: "[T]he most regrettable case of all, which unfortunately is far too common in this country, is that of the man who has something to say, but not much. [The demands of the employer] make it practically impossible for a writer to retire into dignified silence . . . or to lie fallow for a while if he is going through a period of sterility." See Albert Van Nostrand, The Denatured Novel 89-90 (1960).

${ }^{80}$ See id. at 88 (describing George Horace Lorimer's insistence that contributors to the Saturday Evening Post write several pieces a year so that "the reader gets in the habit of looking for" the contributor's work). 
sentence that can be done without. ${ }^{81}$

At some point, a work begins to seem complete. That is, others could understand the gist of what the creator seeks to accomplish and may benefit from the work much in the way its creator intended. At that point, an outsider may consider the work ready for public distribution. But the creator may feel quite differently. The creator will compare the work-in-progress with the initial conception to decide whether the work is what he had sought to produce. If he has brought his conception to fruition, then dissemination will begin. But if the creator decides that the work is not yet complete (or the best approximation that his talent will allow), then he will continue his efforts. Further research may lead him to abandon the work or substantially revise it. He may distribute it to colleagues for comment, polish it further, pursue new sources to confirm its accuracy, or rethink particular portions. ${ }^{82}$ Some creators report working for many years on a single project. ${ }^{83}$

It could be argued that by vesting copyright in the creator's employer and thereby taking the decision to publish out of the hands of the creator, the work for hire doctrine promotes the public's interest in timely disgorgement of creative works. The creator may be too much of a perfectionist to grant access to the work at the most desirable moment. While the creator refines the work, others may be unknowingly duplicating her efforts. Thus, the creator's idiosyncracies can bottleneck society's intellectual growth ${ }^{84}$ and produce unknowing duplication of effort. ${ }^{85}$

The employer, by contrast, provides an objective eye, unhampered by the personal preferences of the creator. If the employer thinks the work can be exploited, then it is probable that the work is in a form in which it is useful to others, and if that is so, declaring the work ready for publication produces social benefits. Thus, the work for hire rules again seem to produce a socially

s1 Stefan Zweig, The Future of Writing in a World at War, reprinted in Van Gelder, Writers and Writing at 89 (cited in note 12).

${ }^{82}$ See Harper \& Row Publishers, Inc. v. Nation Enterprises, 471 U.S. 539 (1985).

ss See, e.g., John Updike, Writers on Themselves: Magic, Working Secrets, N.Y. Times $\S 7$ at 1, 28 (Aug. 17, 1986) (Raymond Carver has written twenty to thirty drafts of a story and forty to fifty drafts of a poem; Philip Roth has reported working six months of eighthour days on one page of text; Philip Larkin's optimal output was three poems per year).

${ }^{84}$ See, e.g., Colin Norman, Sharing Research Data Urged, 229 Sci. 632 (1985) (urging that researchers share raw data to promote, among other things, new research).

ss Warren Hagstrom, The Scientific Community $87-91$ (1975 ed.) (desire to refrain from publishing in small pieces in order to "drop a bombshell" may deprive others in the field of information needed for their own research and lead to duplication of effort). 
desirable result. By vesting universities with copyright over their faculty's work, the rules allow universities to prevent professors from withholding the socially useful information contained in their works.

This argument, however, assumes that universities recognize when a work has achieved fruition better than academics themselves and that universities will not force the publication of immature or inaccurate information. An experience at the California Institute of Technology illustrates that these assumptions may be incorrect.

While a theoretical physicist at Cal Tech, Stephen Wolfram developed a computer program to calculate Feynman diagrams in quantum field theory. Because he wanted the computer program to reach other scientists, Wolfram took steps to disseminate it cheaply to other physicists. ${ }^{86}$ Taking the position that copyrights to computer programs were, under its faculty contracts, the equivalent of patents to inventions, Cal Tech asserted copyright over the program and claimed the right to make decisions concerning the program's distribution. Cal Tech, accordingly, ordered Wolfram to stop circulating copies to those who would, presumably, comprise Cal Tech's market for the work.

The result was unfortunate. The program was not in a usable form at the time the dispute erupted. Because Wolfram had (apparently) exhausted his own resources (which is why he had sought input from other scientists) and because no one else at Cal Tech (apparently) had the capacity to work out its remaining problems, the program was never truly completed. Although the program is for sale, it is not in general use. By preventing the fruition of Wolfram's program, Cal Tech arguably hampered the research in quantum theory (and caused Wolfram to leave Cal Tech).

While Wolfram's case may be dramatic, it illustrates that, at least in some instances, only the creator has the peculiar ability to bring his work to completion. ${ }^{87}$ When creativity coincides with financial interest, as in the typical case in which the employer truly can be said to have inspired the work and the employee is essentially a scribe, this kind of incident is not likely to occur. The employer has the sophistication necessary to understand that the

se Gina Kolata, Caltech Torn by Dispute over Software, 220 Sci. 932, 933-34 (1983).

87 See Ruth L. Greenstein, National Security Restrictions on Research, 1983 Wis. Int'l L. J. 49, 50 ("Because scientific research is highly specialized, preventing a particular scientist from working on a project may be tantamount to saying the research itself cannot take place."). 
work is not ready for public distribution, and in any case, it has the capacity to complete it once the employee resigns.

By contrast, in the university context, where the interesting works are at the cutting edge of their fields, there is likely to be no one else besides the creative employee who can evaluate the readiness of the work for publication or carry it to fruition if needed. The originator of the work is, in short, indispensable to the creative effort. In transferring copyright from academics to universities, the work for hire rules thus raise a spectre of premature publication, and sacrifice long-term social interests in the work's development to the university's short-term interest in commercialization.

Premature publication may, in addition, be highly detrimental to the creator's reputation. If, for example, the work contains errors (errors that the employer may lack expertise to discern or correct), the work's distribution will reflect poorly on the author's abilities as an accurate and careful scholar. Even if the work is accurate, but not yet polished, standing in the academic community may be affected. ${ }^{88}$

This erosion of the creator's reputation creates another significant long-term social cost. If the professor is excluded from the lecture circuit, or denied tenure or other job opportunities, important avenues for circulating his ideas are foreclosed. To the extent that these ideas would have made valuable contributions to the stock of knowledge, society is further impoverished, and first amendment values intruded upon.

It would, of course, be possible for a university to relinquish contractually to a faculty member the right of first publication. ${ }^{89}$

s8 See Note, Copyright and Privacy Protection of Unpublished Works-The Author's Dilemma, 13 Colum. J. L. \& Soc. Prob. 351, 366 (1977); Hagstrom, The Scientific Community at 26-27 (cited in note 85). Hagstrom notes that the effect of errors on reputation can be radically different depending on the scholarly discipline. Thus, an administrator familiar with one field may underestimate the effect that error will have on the career of a scholar in a different field.

Of course, the unfettered right to choose the time of first publication is threatened in other important ways by the new Copyright Act. Because federal copyright now attaches at an earlier stage in the creative cycle (at fixation rather than publication), common law protections are divested earlier. 17 U.S.C. $\$ 102$ (1982). The result is that unpublished works may be subject to the fair use doctrine. But see Salinger v. Random House, Inc., 1 U.S.P.Q.2d 1673, 1679 (2d Cir. 1987) (scope for fair use of unpublished work is narrow because of the impact of premature publication on the market for creator's own version of the work). Similarly, the duration limitations of copyright in unpublished works threaten these interests.

s8 See 17 U.S.C. $\S 201$ (d) (rights under the 1976 Act may be conveyed "in whole or part"). 
By vesting a faculty member with authority to determine when her work had reached fruition, such assignments would prevent the work for hire provisions from allowing a university to force premature publication. Bifurcating the decision to publish from the other rights contained in the copyright might, however, engender problems of its own. In the ordinary case, where the same party owns both the right to withhold the work and the right to all of the benefits that flow from the work's publication, the advantages that accrue upon dissemination encourage the creator to part with the work. But creators who cannot internalize the benefits of publishing may be inclined to refuse to publish even when further work is not cost-effective..$^{90}$ Not only will others lose the advantage of having the work sooner, but the creator's own intellectual resources will be misspent as well. ${ }^{91}$

${ }^{20}$ That is, the creator publishes when the marginal benefit that would be obtained from another revision is less than the cost of continuing to withhold the work. See also Yoram Barzel, Optimal Timing of Innovations, 50 Rev. Econ. \& Stat. 348, 354 (1968) (if the innovator cannot "capture all the generated benefits, his optimal time of introducing the innovation will be later than would be desirable from the social viewpoint").

o1 Stephen Wolfram's experience illustrates another set of potential conflicts. The creator may wish to put his material into the public domain in order to help his professional colleagues, while the university may prefer to exploit the work commercially by selling to these same "customers." If the university prevails, the decision will conflict with the creator's objectives because some of the people he would like to have use his work may refuse to pay the market price. Another illustration of this point is provided by Robert Hellawell, A Computer Program for Legal Planning and Analysis: Taxation of Stock Redemptions, 80 Colum. L. Rev. 1363 (1980). Professor Hellawell chose to publish a computer program that he had developed to treat a common problem in the corporate tax field. Although the program probably could have been marketed commercially, the author used it as a pedagogic opportunity to demonstrate the role that computers can play in "the lawyer's central work of legal planning and analysis." Id. at 1363. One can, of course, only guess whether the work would have had the same circulation (or the same audience) that it enjoyed in the Columbia Law Review had it been sold by a software company.

If the work is to be patented or exploited as a trade secret, even very limited circulation may endanger the university's financial interests. If the university fails to apply for a patent within a year after publication of a paper describing the invention, it will meet the patent bar of 35 U.S.C. § 102(b) (no patent may issue on an invention that was "described in a printed publication in this or a foreign country or in public use . . . in this country, more than one year prior to the date of the application"). Trade secrets are not protectable (or useful) if they become widely known. See, e.g., USM Corp. v. Marson Fastener Corp., 392 Mass. 334, 467 N.E.2d 1271 (1984). Accordingly, the university sometimes may wish to prevent publication or defer it for longer than the creator feels is optimal. See Varrin and Kukich, 227 Sci. at 386 (cited in note 72). An illustration is provided by Guy Charest, Split Information, Stock Returns and Market Efficiency-I, 6 J. Fin. Econ. 265 (1978), and Guy Charest, Dividend Information, Stock Return and Market Efficiency-II, 6 J. Fin. Econ. 297 (1978). Professor Charest devised trading rules that would have generated profit-making opportunities from stock split and dividend information-had he kept them secret. Instead, he chose to publish the information to advance economists' understanding of market performance and (presumably) enhance his reputation as a scholar. See Editorial, Scientists 


\section{Dissemination}

On one point I would wish you to be careful. I would like the printer to follow the manuscript accurately in punctuation and arrangement. Inverted commas, for instance, to enclose dialogue always seemed to me a great eyesore. ${ }^{92}$

What to James Joyce was a "great eyesore" is to many readers an indispensable aid to understanding meaning. But whatever position one might take on quotation marks, italics, colored ink, ${ }^{93}$ place names, or nasty language, ${ }^{94}$ the disputes that arise between creators and publishers illustrate that even after a work is complete, many significant decisions remain for resolution. While questions regarding use of particular language and typography may seem of little moment, these disputes are conceptually identical to larger questions that arise in the process of dissemination. The character and accessibility of a work are inevitably (and usually irretrievably) intertwined with distribution decisions, such as whether the work is published in book or serial form, ${ }^{95}$ in a more or less prestigious journal, and with or without retention of copyright. Furthermore, the outcome of these decisions can have significant repercussions on the reputation and career of the creator.

As we have seen with respect to the issues of conceptualization and fruition, optimal resolution of the problems of dissemination is likely to occur when the creative party owns all rights pertaining to the work. Publication of Dubliners provides a nice example. The process of publishing the work took seven years because James Joyce insisted, among other things, on several uses of the word "bloody," which his publisher thought obscene. Joyce's intransi-

Who Hog Data, N.Y. Times E20, col. 1 (July 28, 1985) (scientists who fail to publish data inhibit research effort of others).

"2 Herbert Gorman, James Joyce 147 (1939) (citing a letter from Joyce to his publisher, Grant Richards).

os See Letter from William Faulkner to Ben Wasson (1929), reprinted in Joseph Blotner, ed., Selected Letters of William Faulkner 44 (1977) (concerning The Sound and the Fury) ("I think italics are necessary to establish for the reader Benjy's confusion; that unbroken-surfaced confusion of an idiot which is outwardly a dynamic and logical coherence. To gain this, by using breaks it will be necessary to write an induction for each transference. I wish publishing was advanced enough to use colored ink for such, as I argued with you and Hal in the speak-easy that day.").

-4 See Gorman, James Joyce at 150-57, 212-16 (cited in note 92) (describing Joyce's difficulties in publishing Dubliners because of use of the word "bloody" and references by name to Dublin pubs and personalities).

os See Van Nostrand, Denatured Novel at 92 (cited in note 79) (describing Booth Tarkington's advice on the book-versus-magazine dilemma); id. at 96-99 (describing Sinclair Lewis's problems with serialization of his novels); id. at 46-47. 
gence helped to protect the integrity of his conception. Yet Joyce's desire to communicate served the public's interest in receiving the work-a goal that only publication could achieve. In the end, he compromised and Dubliners came out with some, but not all, of the changes the publisher sought. ${ }^{96}$

The optimal resolution of the tension between the integrity of the work and publication is not as likely to occur if authorship and creativity are severed. To be sure, there may be situations in which an employer is as capable as the original creator of defending the initial conception, proposing imaginative alternatives, and making the best compromises. But this is likely to be true only where the employer was involved from the time of the work's inception. The more remote the employer's knowledge is of the work's initial visions and the more the employer views the work as merely a financial opportunity, the less likely it is that he will be interested in, or capable of, protecting its integrity. As a result, the work may be disseminated inappropriately, ${ }^{97}$ and the creator's reputation may be injured (or not as enhanced as it would have been had the work been properly distributed). Creators may, in consequence, elect to pursue less intellectually risky projects because they give rise to less demanding dissemination decisions.

The employer could try to prevent creative employees' undesirable risk aversion by assigning back the right to control attribution. ${ }^{98}$ This would permit the creator to protect his reputation by removing his name from work whose quality had been impaired by premature publication or editorial compromises. ${ }^{99}$ For several reasons, however, employers are unlikely to give up attribution rights. First, the employer may believe that the creator's name will improve the marketability of the work or enhance the reputation of

${ }^{98}$ See Gorman, James Joyce at 150-57, 212-16, 153-57 (cited in note 92).

o7 See, e.g., Gina Kolata, Heart Attacks at 9:00 a.m., 233 Sci. 417 (1986) (Harvard scientist discovered what may be an important clue to the etiology of heart attacks, and while this information had been published at least fourteen times "in obscure journals," these were ignored by the medical community).

${ }_{88}$ The Copyright Act has little to say about attribution, and most courts treat the right to be recognized as the author of the work as a contractual one. If a natural creator fails to negotiate for attribution privileges, that right is presumed to lie with the copyright holder. See, e.g., Locke v. Times Mirror Magazine, Inc., 1985 Copyright L. Rep. 25,750 (S.D.N.Y. 1985) (right of attribution is not among the exclusive rights enumerated in 17 U.S.C. $\S 106$ ). See also Note, Giving the Devil its Due: Actors' and Performers' Right to Receive Attribution for Cinematic Roles, 4 Cardozo Arts \& Enter. L. J. 299, 306-07 (1985).

op Some writers use pseudonyms on publications with which they are dissatisfied. Larry Gelbart and Paddy Chayefsky, for example, used the names Francis Burns and Sidney Aaron on the movies Rough Cut and Altered States. 
the institution as a whole. ${ }^{100}$ Thus, the employer may demand a great deal from the creator who wishes to remove his name from his work. To the extent that the creator's name serves a signaling function that decreases the public's search costs, withholding his name from the work is also socially undesirable.

Furthermore, relinquishing the right of attribution may mean giving up the right to suppress attribution, ${ }^{101}$ and this too may work against the employer's interests. Obscuring authorship is sometimes a valuable tool for building a product market. If too many creators are involved in a work, its critical reception may be prejudiced. ${ }^{102}$ Similarly, if a single author is highly prolific, the public might begin to suspect that there is too much for any of it to be very good. Concealing the names of certain contributors also can be a way to draw attention to the work of others. ${ }^{103}$ Finally, obscuring authorship allows the employer to develop a trademark, which permits the employer to transfer the goodwill developed by one employee's work to the work of others. Software producers have used this technique in the marketing of their computer programs so that the public will associate the products they enjoy with the company's name rather than with the name of any particular programmer. ${ }^{104}$

Even if employers were willing to assign employees control over attribution, the disadvantages the employee suffers from the

${ }^{100}$ This thinking is widely accepted in the motion picture industry. Because producers believe that films benefit by being associated with the names of famous authors, they are reluctant to remove the name of a contributor from the credits if that name has drawing power. See Kirk Honeycutt, Whose Film is it Anyway?, Amer. Film 35 (May 1981) (describing Joseph Wambaugh's problems in removing his name from The Choirboys). For a related example in the book industry, see Follett v. New American Library, Inc., 497 F.Supp. 304 (S.D.N.Y. 1980) (book written by others attributed to Ken Follett in order to take advantage of his reputation).

${ }^{101}$ See Vargas v. Esquire, Inc., 164 F.2d 522 (7th Cir. 1947) (contract right to use name implicitly included right to suppress it).

${ }^{302}$ The theory is that the work could not have been very good to begin with if it required so many doctors to fix it.

${ }^{103}$ See Merton, 159 Sci. at 57-58 (cited in note 77), describing the dilemma of Nobel laureates concerning use of their names on the articles of younger members of their laboratories: if the laureates' names are included, they are given a disproportionate share of the credit; if their names are omitted, the work may not be published.

104 See Jim Bartimo and David Crane, 9 InfoWorld No. 11 at 84 (Mar. 12, 1984) (describing Atari's institution of this policy). See also Harlequin Enterprises Ltd. v. Warner Books, Inc., 639 F.Supp. 1081, 1085 n.6 (S.D.N.Y. 1986) (describing practice of using "house pseudonyms" for work for hire in order to "lend apparent continuity"); Rita Cruise O'Brien and G. K. Helleiner, The Political Economy of Information in a Changing International Economic Order, 34 Int'l Org. 445, 451 (1980) ("Among the means of reducing qualitative informational uncertainties in a complex world are the development of customer relationships, brand loyalties, reputation, and goodwill."). 
work for hire doctrine may not be eliminated. Exercising suppression rights forces an employee to lose identification with his work, which may be too high a price to pay. The motion picture industry furnishes a good illustration. Beginning screenwriters place a great deal of emphasis on amassing credits, because they feel that a large portfolio (like a long curriculum vitae) is essential when applying for a new position. ${ }^{105}$ Indeed, one of the more disturbing features of the work for hire doctrine is that it apparently permits an employer to interfere with the development of his employees' reputations by disrupting their ability to receive public recognition for their work. ${ }^{106}$

\section{Use}

[S]everal members of the legal profession, and other worthy subjects of this realm, not knowing the contrary, believed the plaintiff to have been the author of [the third edition of a Summary of the Law relative to Pleading and Evidence in Criminal Cases], and to have prepared it for publication, "and to have made and committed the several gross errors, blunders, and mistakes" . . . and that the plaintiff had been, by means of the premises, greatly injured in his reputation, as such barrister and such author. ${ }^{107}$

Publication of a work does not end the creative cycle, for works can be adapted to other uses. A hardcover book can be turned into a paperback, a play, an opera, a motion picture or a television show; it can be translated into a foreign language; and characters from one story can be turned into dolls or made to appear in another story. ${ }^{108}$

${ }^{105}$ See Note, 4 Cardozo Arts \& Enter. L. J. at 335-36 (cited in note 98). For a related example, see Calvin R. House, Good Faith Rejection and Specific Performance in Publishing Contracts: Safeguarding the Author's Reasonable Expectations, 51 Brooklyn L. Rev. 95, 102 (1985) (noting that publication is important to establish a track record and gain bargaining power in the next negotiation). See also Weinstein, 811 F.2d at 1093 (order in which attribution made may affect reputation of author).

${ }^{108}$ It is instructive to note that many programmers resigned when the policy of suppressing attribution was instituted at Atari. See Bartimo, 9 Infoworld No. 11 at 84 (cited in note 104) (describing how the employees formed their own company, Activision).

${ }^{107}$ Archbold v. Sweet, 5 Car. \& P. 219, 221, 172 Eng.Rep. 947, 948, aff'd, 1 M. \& Rob. 162, 174 Eng.Rep. 55 (1832).

${ }^{108}$ See, e.g., G. Ricordi \& Co. v. Paramount Pictures, Inc., 189 F.2d 469 (2d Cir. 1951) (John Luther Long's book, Madame Butterfly, made into a play by David Belasco, a libretto by G. Ricordi \& Co., and an opera by Giacomo Puccini; Paramount produced the motion picture). 
As with many of the issues that arise in the course of the creative cycle, derivative use is a two-edged sword. On the one hand, adaptation presents an interesting opportunity for the creator to rethink the original material and to achieve additional insights into its subject matter. ${ }^{109}$ Reuse of a familiar character may help the creator to elaborate a complex theme. In addition, the new work may appeal to a larger-or at least a different-audience and so disseminate the creator's ideas more broadly. ${ }^{110}$

On the other hand, the public will associate the derivative work with the original. If the creator's adaptation is inartful, the reputations of the creator and his work may be tarnished. ${ }^{111}$ Furthermore, the creator may not wish to undertake the duties entailed in preparing the derivative work. The new material may take as much time and effort to produce as did the original, but yield modest intellectual payoffs. ${ }^{112}$ It is, accordingly, not surprising that many creative individuals report that they generally prefer to move on to new fields rather than to mine old ones fully. ${ }^{113}$

Of course, derivative works are hardly rare. Creators routinely balance the costs of the adaptation against the monetary and intellectual benefits they predict will accrue from the new work. Since the financial reward acts as a proxy for the social benefit generated by the work, the creator in effect weighs the social interest in an adaptation against the risks and costs of devoting his energies to a new task.

109 For instance, adaptation for the IBM PC of a prompting program written originally for an Atari computer required the development of a scrolling program, which was itself an interesting challenge to the programmers. See Q-Co. Industries, Inc. v. Hoffman, 625 F.Supp. 608, 611 (S.D.N.Y. 1985).

110 A well-received book may sell 100,000 hardcover copies, see Daisy Maryles, Hardcover Bestsellers, Publishers Weekly 29 (Mar. 14, 1986), and 50,000 paperback copies, see John Mutter, Paperback Bestsellers, Publishers Weekly 32 (Mar. 14, 1986). A moderately popular movie will be viewed by over eight million people. See Janet Maslin, Comedies Without Laughs Merit Cries of Protest, N.Y. Times § 2 at 19, col. 1 (Feb. 15, 1987).

The capacity of the derivative work to fill demands in new markets may help to explain why translations were not, in the early days of copyright, considered infringements of the original work, and why plays were not considered infringements of books. See Benjamin Kaplan, An Unhurried View of Copyright 29-30 (1967).

${ }^{111}$ Courts have recognized derivative works' potential for harming the original work in connection with joint works. They have imposed on joint authors a duty not to license the work in a manner that will destroy the original or diminish its value. See Shapiro, Bernstein \& Co., Inc. v. Jerry Vogel Music Co., Inc., 73 F.Supp. 165, 168 (S.D.N.Y. 1947); 1 Nimmer on Copyright $\$ \$ 6.11$ and 6.12[A] (cited in note 5).

112 Uses of the original may raise similar concerns. See, for example, Peter H. Levis, The Answer? Sold Separately, N.Y. Times C7, col. 3 (July 1, 1986) (noting high number of queries generated by sophisticated software program).

12 See, e.g., Merton, 159 Sci. at 61 (cited in note 77) (finding that Nobelists tend to change fields more often than other scientists and that, by venturing into little-understood areas, they are able to make greater contributions than they otherwise might have made). 
A similar balance determines the creator's decision among several exploitation opportunities. One choice (publication in a popular magazine, for example) may expand the creator's audience at the expense of his intellectual reputation. ${ }^{114}$ Another may offer an interesting artistic challenge but destroy further adaptation opportunities. ${ }^{115}$ The creator decides where to allocate his intellectual efforts by comparing the costs of each alternative in time and effort, reputational interests, and foregone opportunities with the benefits of wider circulation, intellectual challenges, and financial gain.

When the work is made for hire, however, the benefits of the derivative work are in the hands of the employer, whereas many of the costs accrue to the employee. If the employer was not sufficiently involved in the creation of the initial work, he may find it difficult to gauge accurately the effort required to produce the adaptation or the implications of his choices for future opportunities. This will be especially true where the work is at the forefront of its field and there is no historical exemplar. In addition, the employer/ holder may tend to overvalue the financial benefits (which he perceives) at the expense of the reputational costs (with which his concern may be more attenuated). The employer therefore may be more likely to direct preparation of derivative works whose costs exceed their benefits, or to choose nonoptimal exploitation opportunities.

If the creator disagrees with the employer's decisions, he could refuse to prepare the derivative work. In that case, however, the employer may elect another to fill his place. But if the work is truly at the forefront of its field, it may be difficult to locate someone sufficiently knowledgeable to substitute for the initial creator. Cal Tech, for example, was apparently unable to make Wolfram's program marketable after he decided to abandon the effort. ${ }^{116}$ Even if the replacement manages to create the derivative work, the adaptation may not be as good as the original, ${ }^{117}$ and the employer

${ }^{114}$ See, e.g., Van Nostrand, Denatured Novel at 95-96 (cited in note 79) (Sinclair Lewis believed decision to serialize certain of his novels in magazines harmed the public reception of his books).

${ }^{118}$ Dorothy Sayers, for example, lost all interest in Lord Peter Wimsey after she had married him off to Harriet Vane. See Carolyn Heilbrun, Sayers, Lord Peter and God, 37 Amer. Scholar 324 (1968). Killing off a recurring hero is even more final.

${ }^{116}$ See Kolata, 220 Sci. at 934 (cited in note 86).

11 See Clevenger v. Baker Voorhis \& Co., 8 N.Y.2d 187, 168 N.E.2d 643, 644, 203 N.Y.S.2d 812 (1960) (yearly supplement to Annual Practice of New York prepared by publisher's staff after Joseph Clevenger, an authority on New York law, resigned; new work failed to report changes in law accurately). 
may be unable adequately to perceive its defects. As a result, the work may reflect poorly on the initial creator, endangering his professional standing and his ability to attract the attention of colleagues to his other efforts. ${ }^{118}$ The creator may be unable to make the contribution to society that he could have had his reputation not been unjustifiably tarnished.

The problem is aggravated when the natural author wishes to adapt the work, but the employer refuses to allow him to do so. For example, the employer may think that the benefits to be obtained from the derivative work are lower than the potential gain to be received from other uses of this creative employee's time. Or the employee's interest may develop only after termination of the employment relationship. ${ }^{119}$ In either case, the employer, as holder of the copyright, may refuse to permit adaptation. Indeed, he may opt to have another employee execute the creator's work ${ }^{120}$ or to license the right to the derivative work to a third party. ${ }^{121}$

In any event, vesting the employer with the copyright in a work means that the original creator will be restricted in his ability to make use of his own work. If the initial material had staked out territory that was of particular interest to the creator, this deprivation could represent a severe intellectual loss and a career setback. ${ }^{122}$ It may also result in a social loss, for the initial creator's intimacy with the original may mean that he is the one who could

118 The creator's reputation perhaps could be spared by noting the change in authorship on copies of the derivative work, but this is a solution to which the employer may be unwilling to consent. In any case, the public is likely to associate the derivative work with the original work despite disclaimers by the original author.

110 See, e.g., Siegel v. National Periodical Publications, Inc., 508 F.2d 909 (2d Cir. 1974) (Superman character).

${ }^{120}$ In the university setting, it may be tempting to save money by hiring graduate students, or-even better-by making preparation of the derivative work a part of the degree requirement.

${ }^{222}$ Theoretically, if the employer can predict that the creator will make the best use of the work, he will hire (or license) him. However, if the exclusive rights in the derivative work fail fully to capture the consumer surplus it generates, the employer may lack the incentive to allow the creator to prepare the derivative work. If the portion of surplus that could be earned by the work as prepared by the initial creator minus his salary (or the employee's portion of the royalties in the case of a licensing agreement) falls below the surplus captured by the substitute's work minus his salary, then the employer will make the substitution regardless of the actual relative value of the two works.

122 The significance normally attached to allowing creators to make derivative use of their own works is reflected in the law on the copyrightability of characters. See, e.g., Warner Bros. Pictures, Inc. v. Columbia Broadcasting System, Inc., 216 F.2d 945 (9th Cir. 1954) (permitting Dashiell Hammett to retain rights to use Sam Spade after selling The Maltese Falcon). 
put it to its best use. ${ }^{123}$

The creator's inability to control the derivative uses of his work may even distort his conceptualization decisions. Consider the employee who has the freedom to choose his own projects, but no control over derivative uses of his work. If some works are more susceptible to adaptation, the employee may well refrain from pursuing those projects (even if they present the most socially beneficial use of his time) in order to avoid the damage that would be caused by inaccurate or inappropriate derivative use. ${ }^{124}$ This riskaverse reaction is analagous to that caused by assigning attribution rights to employers. In both contexts, the public welfare decreases as potential, uncontrollable risks curtail creative ambitions.

\section{State Law Alternatives}

While copyright law (as Professor Nimmer observed) deals mainly with questions having pecuniary implications, it does provide a mechanism (albeit an imperfect one) for protecting nonpecuniary interests. Significantly, it performs that function in part by allowing financial considerations to serve as a surrogate for some of the concerns in issue and in part by utilizing pecuniary rewards as a mediator between the creative and their surroundings. Thus, when creativity and financial rights coincide, the creator's abilities are fully utilized to further the public interest. The potential for remuneration encourages the creative to make constructive compromises and gives the public the benefit of bringing their talent to bear both on the qualitative questions involved in producing the work and on the logistical questions of making it usable.

The operation of the work for hire doctrine demonstrates that severing pecuniary and nonpecuniary interests deprives the public of the full enjoyment of the creator's talents. What remains to be investigated, however, is the extent to which state law alleviates

${ }^{123}$ The Seven-Per-Cent Solution, for example, is a nice book, but it is not about the real Sherlock Holmes. Compare Nicholas Meyer, The Seven-Per-Cent Solution (1974) with Arthur Conan Doyle, The Return of Sherlock Holmes (1905).

${ }^{124}$ An argument could be made that since in general creative individuals are often unable to control future use of their work, see Maxtone-Graham v. Burtchaell, 803 F.2d 1253 (2d Cir. 1986) (fair use for antiabortion advocate to use excerpts of book written to promote the right to choose abortion); Shostakovich v. Twentieth Century-Fox Film Corp., 196 Misc. 67, 80 N.Y.S.2d 575 (Sup. Ct. 1948), aff'd, 275 App. Div. 692, 87 N.Y.S.2d 430 (1949) (refusing to enjoin anticommunist film that used music by Soviet composers), there is no reason to fault the work for hire doctrine for producing the same result. The interests protected through the fair use doctrine are, however, substantially different from the concerns at stake in work for hire. 
these deficiencies. Since the creative look to state contract and unfair competition law to protect those values that are inadequately protected through copyright, it is to these doctrines that I now turn.

\section{A. Contract Law}

It could be argued that the statutory assignment of copyright is irrelevant because the parties are free to alter their rights contractually. ${ }^{125}$ But this argument holds only if the social value of putting these rights in the hands of the creator will be reflected in the rewards that are made available to him through ownership of the copyrights to his work. Otherwise, he will not be able to generate enough profit to pay his employer for the copyright assignment. The empirical evidence on this issue in the university context is inconclusive since few exchanges between employees and universities have occurred either before or after the effective date of the 1976 Act. This could mean that universities recognize the benefits of allowing their faculties to control the copyrights to their output, or that these institutions have not yet bothered to claim their privileges under the new law. ${ }^{126}$ In any event, it cannot be empirically demonstrated that academics could protect their interests (and those of the public) by buying back from universities the right to control the copyrights to their work (or by refusing to assign the copyrights to the universities in the first place).

On a theoretical level, several factors make it unlikely that an employee would be able to negotiate successfully for these rights. If we assume that the university would claim copyrights because it perceived an opportunity for pecuniary gain, the employee would have to compensate the university for the financial loss it would sustain by foregoing this opportunity. But if the employee's interests are predominantly in works that produce intangible, nonpecuniary social benefits (benefits that are not easily internalized), ${ }^{127}$

123 See, e.g., Edmund W. Kitch, The Law and Economics of Rights in Valuable Information, $9 \mathrm{~J}$. Legal Stud. 683, 684-88 (1980) (taking issue with the claim that employment restrictions affect the dissemination of information by noting that if there are valuable markets that the employer has not tapped, the employee has the incentive to buy his way out of the contract and fill the demand).

${ }^{226}$ Alternatively, it could mean that universities' assessments of the 1976 Act do not coincide with those of the commentators. Of course, universities could require faculty to assign their rights to copyrightable material to the university, as is done with patent rights.

${ }_{127}$ See, e.g., Copyright Law Revision, Hearings Before the Subcomm. on Patents, Trademarks, and Copyrights of the Senate Comm. on the Judiciary, 90th Cong., 1st Sess. 907, 910 (1967) ("1967 Hearings") (statement of John Stedman) (academic works are differ- 
then ownership of the copyright will not furnish the employee with the means to bargain successfully.

There is certainly a class of works for which the copyright system provides the holder with a return commensurate with the social utility produced, that is, a class of works for which initial assignment of rights will not matter. Yet this is not always true, and in fact, it is unlikely to be true if the work is highly innovative-as is often the case with academic work. ${ }^{128}$

One reason that copyright fails fully to capture consumer surplus is that copyright holders usually cannot discriminate perfectly in price among the users of their works. ${ }^{129}$ Since the users of a copyrighted work are usually charged the same price, ${ }^{130}$ the copyright holder cannot extract the full surplus experienced by those who value the work most highly. In addition, the holder forgoes sales to those potential users who assign a value to the work below the set price. ${ }^{131}$ Works at the forefront of their disciplines are particularly vulnerable to this problem because of the difficulty in predicting their utility. A work at the frontier is hard to evaluate and carries a high risk of proving useless. Consumers will accordingly discount the expected benefit by this risk when deciding what they are willing to pay for the work. ${ }^{132}$ The copyright holder will be forced either to sacrifice sales he would have made had the potential benefit been accurately measured, or to price the work well below the cost that reflects its actual utility. ${ }^{133}$

ent from popular works in both the motivation behind their creation and the social significance of their use).

128 Some university-generated materials, such as textbooks, will not suffer from these evaluation problems. Accordingly, it may be irrelevant to whom the statute assigns copyright ownership, apart from the unsettling effect on faculty expectations.

${ }^{129}$ See Jack Hirschleifer and John G. Riley, The Analytics of Uncertainty and Information-An Expository Survey, 17 J. Econ. Lit. 1375, 1404-06 (1979); Breyer, 84 Harv. L. Rev. at 285-86 (cited in note 2).

130 There are, of course, exceptions, but these apply to multiple uses rather than to more valuable ones. For example, many journals charge libraries a premium for subscriptions, but this differential is most likely due to the fact that the library price encompasses use by many individuals, some of whom reproduce the work without paying royalties. See $S$. J. Liebowitz, Copying and Indirect Appropriability: Photocopying of Journals, 93 J. Pol. Econ. 945 (1985). The pricing of videotapes and computer software may furnish other examples.

${ }^{132}$ The fair use doctrine enables certain marginal users to benefit from the work by excusing infringement. See 17 U.S.C. § 107. This, however, exacerbates the problem of capturing the surplus in scholarly writings, because fair users are not required to pay the copyright holder.

${ }^{132}$ See Gordon, 82 Colum. L. Rev. at 1607-08 (cited in note 69).

${ }^{138}$ This may explain why many scholarly journals (for example, law reviews) cannot recover their production expenses from subscription fees. 
Furthermore, because of its limited duration, copyright is an inaccurate proxy for social value whenever the benefits of the work are not immediately recognizable - as is again the case with a great deal of scholarly writing. If the work is not understood until after its copyright expires, the holder will never have the opportunity to capture the social wealth that the work generates. ${ }^{134}$ Once again, the more avant-garde the work, the more vulnerable it is to undervaluation by the copyright mechanism. ${ }^{185}$ Works produced by individuals who express the desire to defy society are especially likely to suffer, because their works are intended to challenge accepted principles and reveal defects in the social structure. Like important Supreme Court dissents, these works may be poorly received when written, yet they may ultimately prove more valuable than contemporary works that meet with greater popular acclaim.

In addition, limits on copyright protection such as the fair use doctrine ${ }^{138}$ and the idea/expression dichotomy ${ }^{137}$ have greater impact in the area of scholarly writings than in any other. Many uses of copyrighted works that occur in the university setting are specifically mentioned as fair uses under the statute, ${ }^{138}$ and it is likely that the works used in this setting were also created in it. Moreover, because most scholarship is primarily intended to convey ideas and reveal results of factual research, its benefits often can be enjoyed without paying tribute to the copyright holder. ${ }^{139} \mathrm{Fi}$ -

234 See Edith Tilton Penrose, The Economics of the International Patent System 30 (1951) ("The arbitrary limitation of the patent to the same period for all inventions irrespective of the time and expense it takes to perfect them and to develop a market for them may well result in the more difficult and elaborate inventions receiving a smaller 'index' of usefulness than the easily developed, easily marketed inventions that catch the popular fancy quickly.").

${ }^{135}$ Advances in mathematics nicely illustrate this point. When they are first published, papers in theoretical mathematics often appear to have little relevance outside their field; yet they often become significant when discoveries in other sciences "catch up." See, e.g., Gina Kolata, Solving Knotty Problems in Math and Biology, 231 Sci. 1506 (1986), which describes how theoretical work in the mathematics of knots-originally undertaken in the 1920 s-is just now helping biologists unravel the secrets of DNA.

13817 U.S.C. \& 107.

${ }^{237} 17$ U.S.C. \$ 102(b). The idea/expression dichotomy is a formal recognition of the doctrine that copyright does not extend to facts and ideas. "The very object of publishing a book . . . is to communicate to the world the useful knowledge which it contains. But this object would be frustrated if the knowledge could not be used without incurring the guilt of piracy of the book." Baker v. Selden, 101 U.S. 99, 103 (1879).

138 Section 107 specifically mentions scholarship and research as fair uses and includes nonprofit educational usages as one of the factors to be considered in deciding whether a use is fair. See also 17 U.S.C. $\S 108$ (reproduction by libraries) and $\S 110(1)$, (2) (exemption of performances for face-to-face teaching activities).

139 See, e.g., Hoehling v. Universal City Studios, Inc., 618 F.2d 972 (2d Cir. 1980). For a similar case, see Ehat v. Tanner, 780 F.2d 876 (10th Cir. 1985) (scholar not entitled to com- 
nally, the problem is somewhat cumulative. The utility of scholarly writing lies primarily in the contribution it makes to the work of others. ${ }^{140}$ If the creator who uses a previous work cannot fully internalize the benefits of the new work he creates, he will not be willing to purchase the work he has used for its full value.

A similar equation holds as between the employee and his employer. If the copyright captures the benefits that the work creates, the employee can use his expectations to bargain for transfer of the right from the employer. But if the long-term value of the work is greater than the market's current evaluation (as with controversial material), or if the employee cannot fully internalize the market evaluation (as, for example, during a fallow period), then the employee will lack the ability to buy the right to use the copyright system to maintain control over his works. As a result, these rights will, in all probability, remain with the university (if the university asserts its interest in them).

In time, the mix of work created in the university setting may begin to change as universities subtly redirect their efforts toward works whose financial benefits are more easily captured, and as faculty members attempt to avoid the risks associated with producing works requiring sensitive fruition, dissemination, and usage decisions that they lack the power to control. If the university is not regarded as an important source of innovative materials, it may be unimportant that the mix of output can be expected to change. But if society relies upon academia as a mainspring of intellectual progress-and the concept of academic freedom may well stem from this perception of the university-then this alteration would be a profound one. ${ }^{141}$

pensation when notes stolen from his office were sold to the public). See generally Jane C. Ginsburg, Sabotaging and Reconstructing History: A Comment on the Scope of Copyright Protection in Works of History After Hoehling v. Universal City Studios, 29 J. Copyright Soc. 647 (1982) (noting that scholarly theories are considered uncopyrightable as facts and suggesting an analysis leading to greater protection of historical works); Robert A. Gorman, Copyright Protection for the Collection and Representation of Facts, 76 Harv. L. Rev. 1569, 1571 (1963) (copyright is not "the ideal vehicle for the protection of factual works").

${ }_{140}$ See, e.g., Brubacher, Bases for Policy at 83 (cited in note 74) (speaking of scholarship as "a beachhead for further advances"); A. Carl Leopold, The Act of Creation: Creative Processes in Science, 28 Bioscience 436, 439 (July 1978); Ginsburg, 29 J. Copyright Soc. at 661 (cited in note 139) (speaking of making knowledge "freely available to the intellectual marketplace as building blocks to discovery of the truth").

${ }^{141}$ The change in the universities' emphasis could, of course, lead to the growth of think tanks and other centers of intellectual development, but the search for funds that would occur in these settings would return us to the same set of concerns. See Gideon Chagy, The New Patrons of the Arts 72-79 (1973) (discussing the effect of increased corporate patronage on the freedom of artists, and hence the quality of the arts, and contrasting 


\section{B. Unfair Competition}

Because of the traditional focus on financial incentives for innovation, there are many contexts in addition to work for hire in which copyright law gives sparse attention to author-based considerations. ${ }^{142}$ Where this is the case, creators generally fall back on the "quasi-moral rights"143 formed by the laws of unfair competition, defamation, and other tort actions, by state statutes and the law of remedies. It could be argued that if creative employees can, like other authors, utilize these doctrines to protect their interests, then transferring copyright to employers is of little significance.

Consider, for example, the possessory, integrity, and reputational interests identified above. In many respects, these values are severely compromised by copyright law. The fair use doctrine, for example, is regarded as an essential limitation on copyright because it enables others to build upon earlier works and advance the frontiers of knowledge. ${ }^{144}$ At the same time, however, the unauthorized uses that it permits can destroy the integrity and the impact of the initial work and color the public's perception of it. ${ }^{145} \mathrm{Be}-$

corporate patronage with a system of private individual support of the arts).

${ }_{142}$ See Kaplan, An Unhurried View at 69, 75 \& n.115 (cited in note 110) (noting that copyright secures only partial creative control); Kwall, 38 Vand. L. Rev. at 68-70 (cited in note 51) (noting compromises made in the name of public access interests); Note, Copyright and Privacy Protection of Unpublished Works-The Author's Dilemma, 13 Colum. J. L. \& Soc. Prob. 351 (1977); Note, Personal Letters: A Dilemma for Copyright and Privacy Law, 33 Rutgers L. Rev. 134 (1980); Comment, The 1976 Copyright Act and Preemption of Private Letters, 13 John Marshall L. Rev. 205 (1979); Bayard F. Berman and Sol Rosenthal, Screen Credit and the Law, 9 U.C.L.A. L. Rev. 156 (1962).

${ }^{163}$ I take this term from the French concept of "droit moral"-moral rights that protect the creator's ability to control disclosure, withdrawal, paternity, and integrity. See Law of March 11, 1957, [1957] J.0. 2723, 4131; Raymond Sarraute, Current Theory on the Moral Right of Authors and Artists Under French Law, 16 Amer. J. Compar. L. 465 (1968). Moral rights theorists have always held the view that advancing the interests of the creator simultaneously furthers the public interest.

The Berne Convention for the Protection of Literary and Artistic Works also protects moral rights. See art. 6 bis, 123 L.N.T.S. 233, 249, reprinted in 3 UNESCO Copyright Laws and Treaties of the World (1971). The United States is not, however, a party to the Berne Convention, and thus protection of these rights here depends heavily on the state laws discussed in the text. See generally Subcomm. on Patents, Trademarks, and Copyrights, Senate Comm. on the Judiciary, 86th Cong., 1st Sess., Copyright Law Revision Study No. 4: The Moral Right of the Author 141 (Comm. Print 1960) (prepared by William Strauss) (discussing correspondence of American law to droit moral).

144 See, e.g., Rosemont Enterprises, Inc. v. Random House, Inc., 366 F.2d 303 (2d Cir. 1966); Time Inc. v. Bernard Geis Assocs., 293 F.Supp. 130 (S.D.N.Y. 1968); Lionel S. Sobel, Copyright and the First Amendment: A Gathering Storm?, 19 Copyright L. Symp. (ASCAP) 43 (1971); Note, 13 Colum. J. L. \& Soc. Prob. at 373-77 (cited in note 142).

${ }^{145}$ See, e.g., Gilliam v. ABC, Inc., 538 F.2d 14 (2d Cir. 1976) (edited version of television show removed key scenes, making story incomprehensible). See also Leslie Bennetts, "Colorizing" Film Classics: A Boom or a Bane?, N.Y. Times A1, col. 3 (Aug. 5, 1986), for an 
cause the doctrine may allow the user to associate unauthorized adaptations with the creator and ascribe to him beliefs that he does not hold, it has the potential to tarnish, if not destroy, the creator's reputation.

Similarly, Congress's 1976 decision to preempt state common law copyright and to protect unpublished work federally ${ }^{146}$ undermines the creator's ability to control release of his material. Unpublished works may now be vulnerable to unauthorized fair uses; ${ }^{147}$ and, of course, they fall into the public domain upon the expiration of copyright. ${ }^{148}$ Such premature releases expose the creator (and those who appear in his works) to public scrutiny, ${ }^{149}$

almost literal example of the statement made in text. The article describes Frank Capra's effort to prevent computer colorization of his classic black-and-white film, "It's a Wonderful Life," after its copyright expired, on the ground that enjoyment of the original version would be impaired.

Anyone familiar with the commercial jingle for Quaker Puffed Wheat (and Rice) that begins "This is the cereal that's shot from guns," and who then has tried to listen to Tchaikovsky's "1812 Overture," has suffered the experience of having an exciting work permanently ruined. Similarly, Strauss's "Blue Danube Waltz" loses its magic to those familiar with the advertisement of the Rival Dog Food Company ("Give me Rival Dog Food, arf arf, arf arf.").

It should be noted that some of these examples do not raise the issue of unauthorized adaptations. Rather, they involve the adaptation of works that have fallen into the public domain. They are, however, useful illustrations of my point about integrity and public perception.

${ }^{148}$ Contrast Copyright Act of 1909 at $\S 10$ (copyright secured by publishing the work with notice of copyright) and $\S 2$ (prior to the publication, works protected by state law) with 17 U.S.C. $\S 102(a)$ (federal copyright protects all works fixed in a tangible medium of expression) and $\S 301$ (preempting state law protection).

147 In Harper \& Row Publishers, Inc. v. Nation Enterprises, 471 U.S. 539, 566-68 (1985), the Court left open the possibility that fair use can now be used to defend unauthorized prepublication, since it limited its decision to cases in which prepublication eroded the copyright holder's market. But see Salinger v. Random House, Inc., 1 U.S.P.Q.2d 1673, 1677 (2d Cir. 1987) (acknowledging ambiguity in the Harper \& Row case, but holding that unpublished works "normally enjoy complete protection against copying any protected expression").

There is some dispute about whether the common law protected unpublished works from fair use. Compare Golding v. RKO Radio Pictures, Inc., 193 P.2d 153, 163 (Cal. Dist. Ct. App. 1948), aff'd, 221 P.2d 95 (Cal. Sup. Ct. 1950); Stanley v. CBS, Inc., 35 Cal.2d 653, 661, 221 P.2d 73, 78 (1950) (no fair use); and Comment, 13 John Marshall L. Rev. at 217 (cited in note 142) (no fair use at common law for unpublished works), with Francione, 134 U. Pa. L. Rev. at 544 n.137 (cited in note 39) (arguing that the common law did not bar fair use of unpublished material).

14817 U.S.C $\S 302$ (duration of copyright for works created on or after Jan. 1, 1978), $\S 303$ (duration for works created but not published or copyrighted before Jan. 1, 1978), § 304 (duration for works published and copyrighted before Jan. 1, 1978).

119 For examples of materials that could have been kept secret under common law copyright that will now automatically fall into the public domain (if not destroyed or voluntarily published), see Chamberlain v. Feldman, 300 N.Y. 135, 89 N.E.2d 863 (1949) (unpublished Mark Twain short story); Baker v. Libbie, 210 Mass. 599, 97 N.E. 109 (1912) (Mary 
which may inhibit his urge to experiment, ${ }^{150}$ lead him to destroy early drafts prematurely, ${ }^{151}$ or induce him to take expensive precautions to keep his work hidden. ${ }^{162}$ Even so, the desire to make unpublished materials "available for research or publication without the risk of infringement claims"15s has apparently prevailed over the interest in privacy. ${ }^{154}$

\section{Baker Eddy's letters).}

An interesting example of the social effect of making private material available is provided by the works of Sigmund Freud. See Daniel Goleman, Freud's Mind: New Details Revealed in Documents, N.Y. Times C1, col. 2 (Nov. 12, 1985). Freud's papers, which contain his diaries as well as treatment notes on his patients, apparently reveal, among other things, that Freud was not particularly faithful to his own theories of psychotherapy. While this revelation may help modern analysts understand why traditional Freudian therapy does not work, the view of Freud that emerges from his papers detracts from his authority in the field. At this point in the history of psychology, altering the public's perception of Freud may not matter; earlier revelation of the papers would probably, however, have impaired the influence that Freud had on his successors. In addition, the papers contain personal information about his patients, some of whom outlived Freud by many years.

${ }^{180}$ See Anthony T. Kronman, The Privacy Exemption to the Freedom of Information Act, 9 J. Legal Stud. 727, 734-35 \& n.27 (1980) (faulting the Freedom of Information Act's goal of monitoring official conduct on the ground that the right to inspect files makes officials "likely to express themselves more cautiously in writing, and to substitute oral for written communication"; noting that a similar result occurs as a result of the Buckley Amendment, 20 U.S.C. $\$ 1232 \mathrm{~g}(\mathrm{a})$ (1982), which permits students to see their school records). But working out solutions to new problems often requires written experimentation, or a sounding board in the shape of a helpful colleague. See Estate of Hemingway v. Random House, Inc., 23 N.Y.2d 341, 244 N.E.2d 250, 296 N.Y.S.2d 771 (1968). The inability to experiment aloud may result in abandoning the problem or finding less fruitful solutions.

${ }_{151}$ Works may be destroyed under any rule of law; the central issue is how to handle works that have survived. The 1976 Act establishes a blanket, automatic rule, which will probably work well for some works, but will allow creative interests to be impaired for others. Under prior law, the creator and his heirs had the right to decide when works should be released, and they could tailor their decisions to the particular needs of the situation. Although creators and heirs can make mistakes, there is little reason to believe they will reach erroneous results any more often than will the government, especially when the latter operates through blanket rules.

${ }^{282}$ See Posner, 28 Buffalo L. Rev. at 9-11 (cited in note 77).

${ }^{183}$ Subcomm. on Patents, Trademarks, and Copyrights, Senate Comm. on the Judiciary, 86th Cong., 2d Sess., Copyright Law Revision Study No. 29: Protection of Unpublished Works 33 (Comm. Print 1961) (prepared by William Strauss).

${ }^{104}$ This is not to say that Congress was wrong to accelerate the advent of federal protection. Publication with notice was a poor way to decide when works were federally protected, because it led to inadvertent loss of rights. To prevent innocent distributions from working forfeitures, courts struggled to find that certain disseminations were too "limited" to trigger application of the 1909 Act. See, e.g., King v. Mister Maestro, Inc., 224 F.Supp. 101 (S.D.N.Y. 1963). By making federal protection automatic upon fixation, this problem is avoided. The decision to protect unpublished works federally does not, however, require that all works be treated equivalently. Congress could, for example, have expressly included lack of publication as a factor in the fair use analysis of $\S 107$, and provided for a longer term of protection. Although this would have required courts to determine when a work had been published, that task has not disappeared in any event. For example, works published before January 1, 1978 are not federally protected under the new act, 17 U.S.C. § 303; expi- 
But despite the ease with which federal copyright law trades off control in the interest of public access, the concerns of the creative are often protected by state law. The interest in deciding when material is ready for publication provides a useful illustration. While the duration limitations and fair use doctrine combine to provide somewhat thin protection for this interest under copyright law, the right of publicity ${ }^{155}$ and the law of ideas-contract ${ }^{156}$ and trade secret law ${ }^{157}$ - do, in some circumstances, enable a creator to prevent others from releasing concrete, valuable information without authorization. ${ }^{188}$ For example, a writer who gives a colleague a preliminary draft of an article may, because of the fair use doctrine, be powerless to use copyright to prevent the colleague from quoting from the work. But unauthorized use of the article may be actionable under state law as a breach of confidence, with the promise of confidentiality inferred from the collegial relationship. ${ }^{168}$

ration of copyright in anonymous and pseudononymous works is determined, in part, from the date of publication, $\S 302(\mathrm{c})$; and the effect of an omission of notice depends on whether the work was registered within five years of publication, $\S 405(a)(2)$.

${ }_{13 s}$ See, e.g., Zacchini v. Scripps-Howard Broadcasting Co., 433 U.S. 562 (1977) (allowing performer to prevent exposure of work in unauthorized medium).

1se See, e.g., Stanley v. CBS, Inc. 35 Cal.2d 653, 221 P.2d 73 (1950) (protecting a concrete idea on the theory that the submitter had received an implied promise that it would not be revealed). See also H.R. Rep. No. 94-1476, Copyrights Act, 94th Cong., 2d Sess. 132, reprinted in 1976 U.S. Code Cong. \& Admin. News 5659, 5748 (noting that action for breach of trust or confidentiality would survive the new Act).

${ }^{167}$ See, e.g., Forest Laboratories, Inc. v. Formulations, Inc., 299 F.Supp. 202 (E.D. Wisc. 1969) (action for illegal use of trade secrets is available to redress wrongful use or disclosure of confidential process prior to the patenting of the process), rev'd on other grounds as Forest Laboratories, Inc. v. Pillsbury Co., 452 F.2d 621 (7th Cir. 1971). Trade secrets may be kept indefinitely. See Warner-Lambert Pharmaceutical Co., Inc. v. John J. Reynolds, Inc., 280 F.2d 197 (2d Cir. 1960) (contract requiring perpetual payment of royalties for use of the formula for Listerine is enforceable despite the fact that the formula is public knowledge). In some jurisdictions, defendants who improperly acquire trade secrets can be forever enjoined from using them. See, e.g., Shellmar Products Co. v. Allen-Qualley Co., 87 F.2d 104 (7th Cir. 1936).

${ }^{158}$ See generally Sophia Davis, State Moral Rights Law and the Federal Copyright System, 4 Cardozo Arts \& Enter. L. J. 233 (1986); Kwall, 38 Vand. L. Rev. 1 (cited in note 51) (investigating the extent to which moral rights are protected under the Copyright Act of 1976 and related state law).

${ }^{259}$ See, e.g., Abernathy v. Hutchinson, 3 L.J. Ch. 209 (1825) (publication of lectures delivered to class of which defendant was a member held a breach of confidence); Carpenter Foundation v. Oakes, 26 Cal.App.3d 784, 103 Cal.Rptr. 368 (1972) (publication of writings transferred in confidence); Doe v. Roe, 42 App.Div.2d 559, 345 N.Y.S.2d 560 (1973) (publication of patient case history held breach of confidence), aff'd, 33 N.Y.2d 902, 307 N.E.2d 823, 352 N.Y.S.2d 626 (1973). See also Smith v. Weinstein, 578 F.Supp. 1297 (S.D.N.Y. 1984) (breach of confidence issue should be adjudicated in state court if federal court fails to find copyright infringement), aff'd, 738 F.2d 419 (2d Cir. 1984). 
Similarly, the power to defend reputational interests and preserve a work's integrity finds support in the law of torts, trademarks, and unfair competition. When a subsequent usage corrupts the original work and the initial author wishes to disassociate himself from it or have it suppressed, courts have been willing to grant relief upon a finding that the association is defamatory, ${ }^{160}$ a misrepresentation of the work's origin, ${ }^{161}$ a misappropriation of the creator's name, ${ }^{162}$ or an invasion of his privacy. ${ }^{163}$

The issue, then, is whether these doctrines are available in the work for hire context, so that those employees who are the moving spirits behind their works have the capacity to utilize them to protect their interests. The Copyright Act does not explicitly resolve

180 See, e.g., Edison v. Viva Int'l, Ltd., 70 App.Div.2d 379, 421 N.Y.S.2d 203, 205 (1979) (if plaintiff can show that "mutilated" version of magazine article destroyed reputation, action for defamation will lie). This right is, however, limited in that the plaintiff must show that the corruption was, in fact, destructive. See, e.g., Geisel v. Poynter Products, Inc., 295 F.Supp. 331, 357 (S.D.N.Y. 1968) (no defamation because defendant's product was too cute to injure plaintiff's reputation).

${ }^{161}$ See, e.g., Gilliam, 538 F.2d at 24 (editing a scene in Monty Python's Flying Circus for commercial television was a breach of contract and violation of the Lanham Act, 15 U.S.C. \& 1125(a) (1982), as a false description or representation of origin); Rich v. RCA Corp., 390 F.Supp. 530 (S.D.N.Y. 1975) (Lanham Act violation); Bonner v. Westbound Records, Inc., 49 Ill.App.3d 543, 364 N.E.2d 570 (1977) (association of composers' names with phonorecords containing other music is a deceptive trade practice under Illinois law and a breach of an implied contractual duty).

${ }_{162}$ See, e.g., Edison v. Edison Polyform Mfg. Co., 73 N.J.Eq. 136, 67 A. 392 (1907). In New York, the right to prevent misappropration of one's name is protected by statute, see N.Y. Civ. Rights Law §§ 50-51 (McKinney Supp. 1986). See also Harold R. Gordon, Right of Property in Name, Likeness, Personality and History, 55 Nw. U. L. Rev. 553, 559 (1960).

18s In particular, association of a creator with causes that harm his reputation may be actionable under the "false light" branch of privacy. See W. Page Keeton et al., Prosser and Keeton on the Law of Torts $\S 117$ at 863 (5th ed. 1984), citing as the seminal case Lord Byron v. Johnston, 2 Mer. 29, 35 Eng.Rep. 851 (1816) (enjoining circulation of poem falsely attributed to Lord Byron). See also Zim v. Western Publishing Co., 573 F.2d 1318, 1327 (5th Cir. 1978) (based on Florida law). To be actionable, however, the disclosure must be embarrassing to a reasonable person. See, e.g., Restatement (Second) of Torts $\S 652 \mathrm{D}$ (1965) (revelation must be "highly offensive to a reasonable person").

Surprisingly, pen names do not receive the same protection. See, e.g., Geisel v. Poynter Products, Inc., 295 F.Supp. 331, 356 (S.D.N.Y. 1968) (no invasion of privacy because "Dr. Seuss" is an assumed name). See generally Prosser and Keeton on Torts $\S 117$ at 851-55.

Another deficiency in copyright law is posed by the first sale doctrine, 17 U.S.C. $\S 109$ (a), which gives purchasers absolute control over the copies of the work. Because the Act considers even an original painting a "copy," id. § 101, the first sale doctrine divests artists of the ability to protect their canvasses from permanent mutilation or destruction. See American Int'l Pictures, Inc. v. Foreman, 576 F.2d 661, 664 (5th Cir. 1978). Several states, have, however, recognized the reputational and social interests involved by providing a mechanism for preventing the unauthorized alteration of creative efforts. See, e.g., The California Art Preservation Act, Cal. Civ. Code $\$ 987$ (West Supp. 1987) (permitting actions to prevent defacement and renounce authorship); Mass. Ann. Laws ch. 231, § $85 \mathrm{~S}$ (Law Coop 1986); N.Y. Arts and Cultural Affairs Law, $\S \S 11.01,14.03$ (McKinney Supp. 1986). 
this issue. Section 201(b) provides that "the employer . . . is considered the author for purposes of this title,"164 which implies that for other purposes-presumably including rights under state law-the employee may consider himself the author of the work.

Nevertheless, it is unlikely that courts will allow employees to fall back on state law doctrine. Under the regime of the 1976 Act, courts start from the premise that the parties negotiated the employment contract against a background rule that transfers authorship as well as copyright protection. As a result, a court may be reluctant, for example, to infer a duty of confidentiality from a contract silent on the issue. The timing of publication affects the value of the work to the copyright holder, and a court may reason that if the right to control dissemination was important to the employee, he should have bargained for it. ${ }^{185}$

By the same token, tort doctrines that give the employee attribution rights are likely to be rejected if the duties they impose derogate from the parties' contract. ${ }^{166}$ Furthermore, because the employer is, in a sense, the "source" of the goods he has had produced, it may be conceptually difficult to fit an employee's challenge into a standard trademark or unfair competition framework. ${ }^{167}$

Most employees are therefore likely to encounter the same fate as the artist Vargas when he attempted to compel his employer, Esquire, to put his name on calendars featuring pictures of

1e4 17 U.S.C. § 201(b) (1982) (emphasis added). See also 132 Cong. Rec. $\$ 4493$ (Apr. 17, 1986) (remarks of Senator Cochran).

${ }^{185}$ Compare Zim, 573 F.2d at 1324-25 (where author made his approval a contractual prerequisite to publication, court will respect this clause, subject to an implicit reasonableness limitation). But see Sargent v. American Greetings Corp., 588 F.Supp. 912, 923-24 (N.D. Ohio 1984) (refusing to enter summary judgment in favor of employer on employee's claim that duty of confidentiality was breached by employer's publication of her work).

Employees may, however, be able to avoid publication of early drafts of their work because of the traditional reluctance of courts to order specific performance. Where the manuscript is demonstrably in existence, however, a court may be more willing to ensure that the employer receives the benefit of his bargain.

${ }^{160}$ See Follett v. New American Library, Inc., 497 F.Supp. 304, 313 (S.D.N.Y. 1980) (author Ken Follett could not prevent publisher from crediting him with co-authorship of work he was hired to edit; Lanham Act did, however, prevent publisher from denominating Follett as principal author).

${ }^{167}$ For this reason, the World Intellectual Property Organization has recommended that European countries adopt special legislation recognizing natural authors as the owners of the moral rights in works that were made for hire. See Report of the Committee of Governmental Experts on Model Provisions for National Laws on Employed Authors, Copyright: Monthly Review of the WIPO 72 (Mar. 1986). The ability easily to separate authorship for copyright purposes from authorship for moral right purposes is, however, unique to countries in which moral rights are considered inalienable. 
his famous "Vargas Girls." The court refused to order attribution on an unfair competition theory, reasoning that

the holding as to unfair competition rest[s] on the premise that the defendants, without the consent or approval of the plaintiffs, had taken and used to their own advantage something in which the plaintiffs had a property right-more specifically, that the defendants had pirated or stolen plaintiff's property and used it in their business in competition with that of the plaintiffs. It is difficult to discern how there could be any pirating or unlawful taking of property ... in view of the rights ... which the plaintiff by contract conferred upon the defendant. ${ }^{108}$

Admittedly, the situation is somewhat altered when the dispute arises between the employee and a third party who is using the work without the permission of either the employee or the employer. In that case, a decision in favor of the employee would not directly impinge upon the rights of the employer, so courts may be more willing to allow the employee to prevail. On the other hand, courts may reason that interference with uses condoned by the employer indirectly diminishes the value of his bargain. ${ }^{169}$ Indeed, courts may not reach the substance of the employee's claim at all. Instead, they may decide that the shift in authorship and ownership that occurs under federal law deprives the employee of standing to assert his state law claims, ${ }^{170}$ or that federal law preempts any state claims that the employee can make in favor of his own interests. ${ }^{171}$

${ }^{108}$ Vargas v. Esquire, Inc., 164 F.2d 522, 526-27 (7th Cir. 1947) (decided under 1909 Act). See also Robert H. Jacobs, Inc. v. Westoaks Realtors, Inc., 159 Cal.App.3d 637, 205 Cal.Rptr. 620 (1984) (permitting employer to revise architectural plan of employee, and refusing to apply California Art Preservation Act to architectural drawings).

${ }^{209}$ Perhaps for this reason, S.2796, 99th Cong., 2d Sess., in 132 Cong. Rec. S12185 (Sept. 9, 1986), which proposed amending the Copyright Act to provide moral rights to artists, limited these rights to works not made for hire.

170 In Moran v. London Records, Ltd., 642 F.Supp. 1023 (N.D. Ill. 1986), for example, the court held that an employee lacked standing to prevent the unauthorized use of his work in the musical composition "Junk." Although the court accepted the proposition that the use was a copyright infringement, it reasoned that under the employment contract, only the employer had the right to sue.

171 See Baltimore Orioles, Inc. v. Major League Baseball Players Ass'n, 805 F.2d 663 (7th Cir. 1986) (baseball players' performance is work for hire, and state-based claims are preempted by copyright law). 


\section{IMPLICATIONS}

The story of the university that lays claims to its faculty work product may seem improbable. But the tale deserves study for its cautionary value to those schools that have, in fact, flirted with the idea of asserting rights to software, texts, and other academic materials. Such a decision is not costless, even if the institution is relatively cautious and waits until work is created before it makes known its interest in it. In exchange for a modest chance of pecuniary gain, the university risks fundamental alterations in the environment it creates for its student body and professional staff. The very strangeness of the story-the fact that the reader intuitively assumes that this scenario will not come to pass-also enhances our understanding of the work for hire doctrine in particular, and the structure of copyright law in general.

\section{A. The Work for Hire Doctrine}

The most cogent criticism of the story is that if it is true that distortions will occur if universities were to claim rights to academic works, then universities dedicated to the advancement of knowledge will instead defer to their faculties' decisions with regard to conceptualization, fruition, dissemination, and use. But if that is the case, then my broader point is established, for that choice would itself reveal the extent to which the coincidence of author-based and economic considerations is perceived as integral to the goal of fostering innovation.

The foregoing study thus suggests that the work for hire doctrine should be legislatively reviewed or judicially limited to the Friendly paradigm. If the work for hire provisions, as interpreted by the commentators, interfere with creators' ability to execute their visions as effectively as possible, then perhaps the commentators' interpretation of the statute is wrong; it is anomalous to construe a law designed to encourage creative efforts in a manner that impedes that objective.

Furthermore, if the commentators' view is correct, the doctrine is more constitutionally suspect than Professor Nimmer's analysis admits. The copyright clause was intended to perform a public purpose; the work for hire provisions would divest the creative employee of the capacity to fulfill that purpose, or require her to buy back the power to fulfill it. Even if the latter option were feasible, there appears to be little justification for demanding that creators internalize the costs of public benefits.

Congress could have followed a more narrow approach. Had it 
expressly considered the effect of the new statute on environments like universities, it might have codified the "teacher's exception" into the 1976 Act. ${ }^{172}$ Failing that, it could have enacted a "shop right" doctrine similar to that used in patent law for works created through the intellectual forces of the employee. ${ }^{173}$ Under this doctrine, the employer would have the limited right to use the work for purposes consistent with his business, but the employee would retain all other rights, including those necessary to safeguard the social values of the work. In that way, the concerns voiced in this article would substantially diminish. ${ }^{174}$

The single exception to this solution may be composite works such as motion pictures-or projects involving several members of an academic department. Congressional rejection of the shop right proposal stemmed, at least in part, from fears expressed by the motion picture industry that their works would be inadequately disseminated if every contributor retained rights to control his portion of the output. ${ }^{175}$ In the same vein, the academic departments

172 See DuBoff, 32 J. Copyright Soc. at 26 (cited in note 6). Duboff notes that while the education lobby participated actively in discussions concerning fair use and photocopying, it took no part in consideration of work for hire. DuBoff concludes from this evidence that "the effect of the work for hire doctrine on academicians was not considered." He suggests that courts should consider re-engrafting the doctrine onto the statute themselves.

${ }^{173}$ See, e.g., 1958 Study at 140 (cited in note 16); 1967 Hearings at 1231 (cited in note 127).

174 It would, of course, remain necessary to determine whether a work was prepared within the scope of emplyment. Like many other issues, this determination is generally easier in the patent context where funding often forms an objective basis for decisionmaking.

${ }^{17 s}$ See Copyright Law Revision, H.R. Rep. No. 2237, 89th Cong., 2d Sess. 115 (1966); Copyright Law Revision Part 3: Preliminary Draft for Revised U.S. Copyright Law and 1962 Discussion and Comments on the Draft, Subcomm. No. 3, House Comm. on the Judiciary, 88th Cong., 2d Sess. 257-75 (Comm. Print 1964); Copyright Law Revision Part 5: 1964 Revision Bill with Discussion and Comments, before the House Comm. on the Judiciary, 89th Cong., 1st Sess. 149-50 (1965) (discussing encyclopedias and other composite works). Motion picture industry representatives argued that if every contributor-actors, writers, composers, directors, set designers-were given a voice in dissemination decisions, exploitation of films would be extremely difficult to achieve and the public would be disserved because the films would be inadequately distributed. See also DuBoff, 32 J. Copyright Soc. at 23 (cited in note 6).

Presumably, under the shop right plan, contributors to a composite work would be considered joint authors. See 17 U.S.C. \& 101 (defining joint work), § 201(a) (providing that authors of a joint work are co-owners of the copyright). Each co-owner is permitted to use or license the work to others, subject to a duty to account. See 1 Nimmer on Copyright, $\$ \S 6.11,6.12[\mathrm{~A}]$ at $6-26$ to $6-28$ (cited in note 5). Although no co-owner would have veto power over the decisions of others, the Act requires that decisions to terminate a grant be effected by majority vote, 17 U.S.C. $\$ 203$ (a)(1), and case law recognizes the right of one coowner to prevent another from granting a license in a manner that destroys the value of the work to others. See, e.g., Shapiro, Bernstein \& Co. v. Jerry Vogel Music Co., 73 F.Supp. 165, 168 (S.D.N.Y. 1947). 
most interested in having their universities assert rights to authorship are those where group research projects are common. ${ }^{176}$ These departments rightly feel that university ownership would simplify dissemination and prevent individual contributors from making unilateral distribution decisions.

However wise Congress may have been in adopting a work for hire doctrine to deal with composite works, it is important to recognize that such material represents a special case. Not every work for hire is like a motion picture. When innovations are created by individuals rather than by teams, there are fewer voices to be heard, and the decisions of one individual are unlikely to compromise the interests of other contributors. ${ }^{177}$ Thus, unless it can be empirically demonstrated that the overwhelming majority of creative works for hire are composite efforts (which seems unlikely), or that it is impossible to articulate a way to distinguish works posing this special problem from all others (which is also implausible), there appears to be little reason to permit considerations applicable only to composite works to determine the law regarding all works made for hire. ${ }^{178}$

In the absence of more responsive legislation, employers who are committed to fostering innovative behavior could adopt less intrusive policies themselves by transferring copyrights to their employees subject to a right to share in the royalties, ${ }^{179}$ or by retain-

178 See University of Maryland Copyright Policy 3 (1979) (one characteristic of a work in which the university asserts ownership interest is "the contribution of more than one university employee other than clerical and secretarial employees").

177 Even in countries with strong protection for creators' rights, special provisions are made for such efforts. See Sarraute, 16 Amer. J. Compar. L. at 473-76 (cited in note 143) (discussing special rules for motion pictures). Significantly, dissemination problems were also considered under the factors test. Courts often tended to find that works were made for hire if it was clear that the work would be more effectively disseminated if it was found to be authored by an employer.

${ }^{178}$ If universities were to claim ownership only in materials that were of the nature of composite works, the issue of determining credit would arise. Determining whether a particular faculty member made a contribution significant enough to be considered an author can be difficult. The movie industry has an arbitration mechanism for dealing with this problem. See e.g., Writers Guild of America, Theatrical and Television Basic Agreement 210, 226-27, 231 (1985); Melvin Simensky, The Importance of Arbitration in Entertainment Industry Dispute Resolution Pt. III, N.Y. L. J. 5, col. 1 (Mar. 15, 1985) (discussing arbitrability of screen credit). Universities would have to develop a similar dispute resolution scheme.

It is interesting to note that the problem is not so evident in patent law, where the shop right doctrine first arose, because the patent statute provides its own mechanism for deciding who is counted as an inventor.

${ }^{179}$ For example, universities could draft employment contracts that require professors to use the profits they earn to reimburse the university for costs associated with producing their scholarship. These costs could include grants awarded, library, secretarial, and research expenses, overhead, and interest for use of the university's money. 
ing only those rights that are necessary to their business interests. If such assignments clearly left dissemination decisions to the natural creator, courts would be more likely to construe them as preserving quasi-moral rights. ${ }^{180}$

It is tempting to equate intellectual property protected by copyright with that protected by patents, and to argue that since the traditional assignment of faculty patent rights to their institutions has not created ill effects, expanding the policy to include copyrights will be costless. But the analogy is imperfect. Reputational interests are not so clearly at stake in patent transfers, because there the university's interest lies in the invention rather than in the scholarly papers describing the discovery. As long as the faculty member retains the right to have the paper attributed to him, attribution with regard to the invention may not be so important. Moreover, the right to recognition is more securely protected by the Patent Act than by copyright law..$^{181}$

Furthermore, the integrity of the work is not as readily jeopardized by working a patent as by inartful exploitation of a copyright: if an invention is tampered with, it will simply fail to function and the public will not use it. A copyrighted work is dangerous to its creator precisely because the public can use it and that use may lead to unwarranted inferences. ${ }^{182}$ Finally, patent rights are more difficult to obtain than copyrights. ${ }^{183}$ Since universities usually have better legal resources than do individual faculty mem-

An arrangement allocating royalties in proportion to the university's support of the project would have an additional benefit. Under current law, a problem is created whenever a faculty member changes posts while in the middle of a research project, for it is unclear whether the former university (which may have sponsored most of the work) or the new one (which is the employer of record at the time of completion) is the author and copyright holder. If, instead, the natural author retained authorship and copyright, this problem would evaporate. Each university would have negotiated a right to a portion of the royalty stream.

${ }^{280}$ Such agreements could be made part of individual employment contracts or codified in the faculty handbook, which would then be incorporated by reference into employment contracts. See DuBoff, 32 J. Copyright Soc. at 36-37 \& n.116 (cited in note 6).

${ }^{181}$ First, the Patent Act protects attribution by requiring that all the inventors join in the application, and that the patent be issued to the first to have discovered the invention. 35 U.S.C. $\S \S 116,102(a)$ (1982). Second, disputes concerning the significance of individual contributions are resolved in the course of the granting of the patent by the Patent and Trademark Office, whose decisions may be relitigated in court. Id. $\$$ 131-35, 141-46.

${ }^{182}$ Of course, inventions can be put to socially undesirable uses, and association with these uses can harm the reputational interests of the inventor. It is, however, instructive to note that joint owners of a patent are not under an obligation to account as are joint owners of a copyright. See 35 U.S.C. $\$ 262$ and note 175 above.

183 Copyright vests automatically. 17 U.S.C. $\$ 201(a)$. Patents, however, are extensively examined by the Patent and Trademark Office before they are granted. 35 U.S.C. $\S \S 131-35$. 
bers, transferring the right to obtain patents often will result in more effective protection as well as more vigorous dissemination. ${ }^{184}$ In contrast, transferring the copyright will often result simply in less sensitive distribution decisions without any corresponding increase in protection.

Universities would also do well to compare the costs and benefits of asserting these rights. The costs, as I have shown, are potentially high. The benefits-the financial reward that is available in the copyrights to scholarly production-are fairly low, except perhaps with respect to computer programs and textbooks. Thus, it is unlikely that the potential profits will ever outweigh the costs that a new regime would impose on the social fabric of the university. Even with regard to texts and software, it is unclear whether claiming copyright is worthwhile. Diverting this income from professors will lower their effective salaries, which may deter people from becoming academics. To attract new talent, universities could raise salaries, but that would drain their financial resources, with little (if any) net financial gain.

Nor are these implications entirely limited to the unique position of universities. Problems with the work for hire doctrine will arise in any setting in which highly original works are created at the intellectual frontiers by parties who are permitted to decide for themselves how to allocate their resources. Magazines, newspapers, and television stations appoint journalists on the basis of their ability to use their own initiative to identify and pursue fertile ideas. Freelance artists, composers, and writers also are hired precisely because they have the capacity to execute imaginative projects with minimal input from an employer. In many of these cases, the work for hire doctrine has the potential for creating the consequences noted in connection with university employment. ${ }^{185}$

186 Commentators have noted in other contexts that the degree of dissemination is dependant on the identity of the holder of the rights. See, e.g., Emilio Q. Daddario, Editorial: Patents, 227 Sci. 1535 (1985) (arguing that dissemination improves when the government turns its patent rights over to private ownership); 131 Cong. Rec. S186-87 (Jan. 3, 1985) (remarks of Senator Dole) (same); 1965 Hearings at 177 (cited in note 11) (statement of Mark Carroll, Ass'n of Amer. Univ. Presses) ("Experience has shown that the Government itself is an ineffective publisher."). See also 132 Cong. Rec. S11100-02 (Aug. 9, 1986) (statement of Senator Gorton) (discussing congressional decision to permit commercial exploitation of government-supported research and strategy of allowing individual researchers to share in the royalties in order to give them incentive to disseminate their work).

${ }^{185}$ Freelancers are particularly vulnerable because they often lack bargaining power, sophistication, and legal representation. See generally Note, 86 W. Va. L. Rev. 1305 (cited in note 18). 


\section{B. The Merged Approach}

The second implication of this discussion concerns the structure of intellectual property law. My argument is that the concerns of authors must be taken seriously in order to further the goals of copyright law. This may be worrisome to those who regard authorbased interests as dangerous obstacles to the free public interchange of ideas, and I do not mean to suggest that public access interests should not be taken into account. Surely progress also requires that creative material be available as building blocks upon which later innovations can be constructed. Moreover, a properly functioning marketplace of ideas dictates that others be permitted to make effective use of an author's creation.

But taking access interests into account does not require that the law devalue author-based considerations. Indeed, these two sets of concerns are not as inconsistent with each other as might be supposed. A close inspection of the "quasi-moral right" doctrines summarized in part III reveals that the common law has, in fact, long been structured around the assumption that the concerns of the creative are aligned, not in conflict, with the access interest of the public. These doctrines therefore offer guidance for producing a legal climate that will be responsive to the concerns of the innovative.

Laws of privilege and confidentiality, for example, clearly result in the sacrifice of information exchange. Yet these laws are enforced precisely because it is understood that protecting communicators can sometimes be of greater social benefit than facilitating access to the substance of their communications. ${ }^{186}$ Enforcing promises of confidentiality in the creative context helps creators maximize the merits of their contributions-"find [their] point of view, [their] emotional outlook at things ... [their] own story"18z - by giving them the opportunity to test their ideas on others without fear of exposing partially formed thoughts to public scrutiny. ${ }^{188}$

18s See, e.g., McCormick on Evidence $\$ 77$ at 171-72 (cited in note 47) (noting that the source of evidentiary privileges lies in the utilitarian goal of protecting relationships that further public policies rather than in notions about human dignity and the need for privacy); Posner, 28 Buffalo $L$. Rev. at 8-10, 17, 20-21 (cited in note 77).

${ }_{187}$ Rosner and Abt, The Creative Experience at 228-29 (cited in note 65) (remarks by Isaac Bashevis Singer).

18s The related action of invasion of privacy may also be inadequate to protect the interests discussed in the text. First, because this action is traditionally based on the personal feelings of the parties, it does not survive death. Accordingly, it may not provide the security necessary to feel free to experiment. Second, the plaintiff is required to demonstrate that 
Unfair competition and publicity rights also put control over public information into private hands as a means for advancing important social policies. ${ }^{18 \theta}$ Even in ordinary commercial cases, these exclusive rights are considered controversial because they are thought to inhibit competition. ${ }^{190}$ Nonetheless, trademarks are widely protected because they provide consumers with signals that prevent confusion, mistake, and deception. ${ }^{191}$

Giving creators control over their reputations functions in much the same way. Like a good trade name, a good reputation enables others to identify the human and intellectual resources that are most likely to contribute to progress. ${ }^{192}$ Thus, the rights to control attribution ${ }^{193}$ and to protect the integrity of the work advance the interests of information users, ${ }^{194}$ whose search costs are reduced when reputations and output are protected from interference by others.

a reasonable person would be highly offended by the disclosure. See Restatement (Second) of Torts $\S 652 \mathrm{D}$. Third, there is no right of action against parties who use the information but who are not actively engaged in the invasion of privacy. See Pearson v. Dodd, 410 F.2d 701 (D.C. Cir. 1969).

${ }^{189}$ See, e.g., J. Thomas McCarthy, Trademarks and Unfair Competition § 1:1 at 3-4 (2d ed. 1984) ("Concerning trademarks it has been said that "the public interest in copying ... yields to the public interest of preventing confusion, mistake and deception in commerce independently of any benefits that may accrue to the trademark owner." "). The Lanham Act's requirements of consumer confusion and use, see, e.g., 15 U.S.C. $\$ 1051(a)(1)$, are best understood as emanating from an intent to protect the consumer rather than the trademark owner. See McCarthy, Trademarks § 23:1 at 42-44. See also Zacchini, 433 U.S. at 576 (right of publicity intended to advance the interest of the public).

180 See, e.g., Ralph Brown Jr., Advertising and the Public Interest: Legal Protection of Trade Symbols, 57 Yale L. J. 1165, 1170-71 (1948).

181 See generally Jules Backman, The Role of Trademarks in Our Competitive Economy, 58 Trademark Rptr. 219 (1968).

${ }^{192}$ See, e.g., Clevenger, 168 N.E. $2 d$ at 645 (predicating finding of libel on possibility of consumer confusion). See also Baez v. Fantasy Records, Inc., 144 U.S.P.Q. 537, 539 (Super. Ct. Cal. 1964) (unauthorized publication of Joan Baez's early recording constituted unfair competition because it would injure her current reputation, her employment opportunities, and success of her future recordings); Smith v. Montoro, 648 F.2d 602, 607 (9th Cir. 1981).

${ }^{193}$ The notice provision of the 1976 Act, 17 U.S.C. $\$ 401$ (b)(3), which requires that the name of the copyright holder appear on publicly distributed copies of the work, is an extremely limited assurance of recognition (since the copyright holder may be the employer or the publisher) and fails to provide any mechanism at all for nonattribution. The creator can, however, usually negotiate for the right to have his name associated with, or dissociated from, his published works. See, e.g., Zim, 573 F.2d at 1325 n.12 (contract provided mechanism for controlling attribution); Granz v. Harris, 198 F.2d 585 (2d Cir. 1952); Clemens v. Press Pub. Co., 67 Misc. 183, 122 N.Y.S. 206 (Sup. Ct. 1910). Some states offer statutory protection, see, e.g., Cal. Civ. Code § 987(d) (West Supp. 1987).

194 The Wolfram/Cal Tech software situation is a good illustration. See also Gilliam, 538 F.2d at 25 \& n.12 ("We find that the truncated version at times omitted the climax of the skits to which appellants' rare brand of humor was leading and at other times deleted essential elements ... of [the] story line."). 
Examination of the preemption issue raised by these state law doctrines neatly bolsters the view that public and private interests are aligned rather than in conflict. ${ }^{195}$ For a time, the Supreme Court held the view that federal law was intended to strike the balance between providing incentives to creativity and safeguarding public access. State rules that offered more protection to creators were found to be preempted. Rights were, in short, either protected federally (to further the incentive interest) or were to be denied entirely (to further access interests). ${ }^{196}$

Significantly, however, the Court has retreated from this position, and it now recognizes that state laws play a significant role in stimulating the creation and dissemination of innovative material. ${ }^{197}$ These rights survive because they do more than prevent "the mere act of reproduction, performance, distribution or display"; 198 giving the individual control over his work simultaneously furthers the social interest in the material he has produced. ${ }^{199}$ Through his rights under state law, the creator is enlisted as a

${ }^{10 s}$ See 17 U.S.C. $\S 301$, which provides that "all legal or equitable rights that are equivalent to any of the exclusive rights within the general scope of copyright . . . and come within the subject matter of copyright . . . are governed exclusively by this title." Note, however, that claims under federal trademark law are not preempted. Id. § 301(d). However, for the remainder of this section, I subsume such claims under "state" rights for purposes other than preemption.

${ }^{198}$ See, e.g., Sears, Roebuck \& Co. v. Stiffel Co., 376 U.S. 225 (1964) (preempting state unfair competition laws that prevent copying of unpatentable products); Compco Corp. v. Day-Brite Lighting, Inc., 376 U.S. 234 (1964) (same).

${ }_{107}$ See, e.g., Aronson v. Quick Point Pencil Co., 440 U.S. 257 (1979); Kewanee Oil Co. v. Bicron Corp., 416 U.S. 470 (1974). See also Goldstein v. California, 412 U.S. 546, 570 (1973) ("[C]ongress has drawn no balance; rather, it has left the area unattended, and no reason exists why the State should not be free to act."). Although Goldstein involved state protection of uncopyrightable material, it has been cited with approval in cases concerning state protection of copyrightable material. See generally Paul Goldstein, The Competitive Mandate: From Sears to Lear, 59 Cal. L. Rev. 873 (1971) (state laws should be upheld if they protect important long-range interests without unduly interfering with the competitive economy); Rochelle C. Dreyfuss, Dethroning Lear: Licensee Estoppel and the Incentive to Innovate, $72 \mathrm{Va}$. L. Rev. 677, 696 (1986) (nonpreemption of state law that protects patented subject matter).

${ }^{288}$ See 1 Nimmer on Copyright $\S 1.01[B]$ at 1-11 (cited in note 5); Kwall, 38 Vand. L. Rev. at 72-77 (cited in note 51).

199 See Douglas G. Baird, Common Law Intellectual Property and the Legacy of International News Service v. Associated Press, 50 U. Chi. L. Rev. 411, 415 (1983); David E. Shipley and Jeffrey S. Hay, Protecting Research: Copyright, Common-Law Alternatives, and Federal Preemption, 63 N.C. L. Rev. 125 (1984); Howard B. Abrams, Copyright, Misappropriation and Preemption: Constitutional and Statutory Limits of State Law Protection, 1983 Sup. Ct. Rev. 509.

Of course, if Congress were to expand the protection offered under copyright, there would and should be a commensurate reduction in state law rights, see 17 U.S.C. $\S 301(b)(3)$. 
"private attorney general" who protects the public interest in the integrity of the culture and assures that work that comes into the public's possession is in its optimal form. ${ }^{200}$ In taking a forwardlooking approach toward fostering creativity, these state laws fill the interstices left by a federal scheme that was founded on essentially static economic principles. ${ }^{201}$

200 French law protects the "moral rights" rights of creators vigorously, and does so, in part, because it recognizes the degree to which the public's interest is aligned with, and protected through, the proprietary rights of creators. See, e.g., John Henry Merryman, The Refrigerator of Bernard Buffet, 27 Hastings L. J. 1023 (1976) (describing interrelationship between personal and public aspects of the moral right).

${ }^{202}$ See Peter Jaszi, When Works Collide: Derivative Motion Pictures, Underlying Rights, and the Public Interest, 28 U.C.L.A. L. Rev. 715, 803-06 (1981) (long view must be taken in deciding what legal rules in fact favor the access interest).

Harper \& Row, Inc. v. Nation Enterprises, 471 U.S. 539 (1985), presents the competing interests quite clearly. If the correct view is that creative interests are subordinate to public access, then Harper \& Row was wrongly decided, for the public's interest in President Ford's memoirs concerning the pardon of Richard Nixon should have been found to outweigh the proprietary interests of the copyright holder. See Francione, $134 \mathrm{U}$. Pa. L. Rev. 519 (cited in note 39). See also Sony Corp. v. Universal City Studios, Inc., 464 U.S. 417, 454 (1984) (unauthorized copying is permissible whenever "it yields societal benefits"). Indeed, the Second Circuit opinion in Harper \& Row, which adopted the theory that the memoirs of public figures are themselves facts that cannot be copyrighted, should have prevailed because it was even more closely attuned to first amendment considerations. See Harper \& Row Publishers, Inc. v. Nation Enterprises, 723 F.2d 195, 204 (2d Cir. 1983), rev'd, 471 U.S. 539 ("Nowhere could the need to construe the concept of copyrightability in accord with First Amendment freedoms be more important than in the instant case. Here we are presented with an article describing political events of major significance, involving a former President of the United States. The paraphrasings concern the very essence of news and of history.").

In reversing the Second Circuit, the Supreme Court demonstrated its concern with the dynamic effect of a public figure exception on the availability of information concerning future public figures. Had the Court accepted the Second Circuit's arguments, the public would have had freer access to a work that had already been created, but parties in the position of President Ford (and his publisher) would have been given little incentive to continue to invest in creative efforts. See 471 U.S.at 546 ("In preparing the book, Mr. Ford drafted essays and word portraits of public figures and participated in hundreds of taped interviews that were later distilled to chronicle his personal viewpoint. It is evident that the monopoly granted by copyright actively served its intended purpose of inducing the creation of new material of potential historical value."). See also Zacchini, 433 U.S. at 576 (upholding Ohio's right of publicity against a first amendment claim on the theory that "the protection provides an economic incentive . . . to make the investment required to produce a performance of interest to the public").

Of course, the Second Circuit did not have to worry about the disgorgement of President Ford's thoughts, because he had testified on the pardon and his testimony was in the public domain. See 723 F.2d at 205, citing Pardon of Richard M. Nixon, and Related Matters: Hearings Before the Subcomm. on Criminal Justice of the House Comm. on the Judiciary, 93d Cong., 2d Sess. 90-151 (1974). But the very availability of the information detracts from the necessity of creating a public figure exception. That is, either this information is available, in which case a public figure exception is not needed to promote the access interest; or the information has not been disgorged, in which case an incentive to produce it is essential. Further discussion of the need to promote disgorgement is found in Robert A. 
Given that the relationship between creative interests and public access is recognized by state law, and that the copyright law has, in effect, utilized economic interests as a surrogate for authorbased concerns, the issue is, then, whether this arrangement is the most efficacious way to encourage and facilitate innovation. It seems unlikely. These state law substitutes for a cohesive approach toward nourishing creativity operate in an entirely fortuitous manner. They depend on creators having the foresight and bargaining power to protect their interests, and on characteristics of the work product that are unrelated to the needs of the creative. Furthermore, because many of the state law doctrines were developed with different aims, and without regard to the public aspects of the problem, the interests of neither information producers nor information users are adequately protected. A more deliberate merger of economic and author-based considerations on the federal level, followed by preemption of these state law doctrines, ${ }^{202}$ would better serve the interests of all involved.

\section{Conclusion}

A decade has passed since the new copyright law was enacted, and during that time, the nation has begun to understand the importance of innovative activity to its well-being. ${ }^{203}$ This examination of the work for hire doctrine is intended to illustrate the many interests that should be encompassed within the "exclusive Right" that the Constitution empowered Congress to provide to "Authors and Inventors." Striking the proper balance between rules that facilitate public access and those that foster creativity will remain elusive, but a dual approach that looks at both economic and author-based considerations is crucial if a coherent system of intellectual property protection is to be fashioned.

Gorman, Fact or Fancy? The Implications for Copyright, 29 J. Copyright Soc'y 560, 561 (1982); Robert C. Denicola, Copyright in Collections of Facts: A Theory for the Protection of Nonfiction Literary Works, 81 Colum. L. Rev. 516 (1981) (offering theories leading to broader protection).

${ }^{202}$ A revised approach to copyright might require a new understanding of the relationship between these statutes, but I defer this to future consideration.

${ }^{203}$ See, e.g., OTA Report at 9 (cited in note 12); 1 The Report of the President's Comm'n on Industrial Competitiveness, Global Competition: The New Reality 18 (1985). 